Original Article

\title{
Anti-osteoarthritic effects of a combination of pomegranate concentrate powder, Eucommiae cortex and Achyranthis radix in rats
}

\author{
Beom-Rak Choi ${ }^{1,2}$, Sae-Kwang $\mathrm{Ku}^{3,4}$, Su-Jin Kang ${ }^{4,5}$, Hye-Rim Park ${ }^{1}$, Mi-Sun Sung ${ }^{1}$, \\ Young-Joon Lee ${ }^{4,5}$, Ki-Moon Park ${ }^{2}$ \\ ${ }^{1}$ Research Institute, HL Science Co., Ltd., Republic of Korea. \\ ${ }^{2}$ Department of Foodscience and biotechnology, Sungkyunkwan University, Republic of Korea \\ ${ }^{3}$ Department of Histology and Anatomy, College of Korean Medicine, Daegu Haany University, Republic of Korea. \\ ${ }^{4}$ The Medical Research Center for Globalization of Herbal Medicine, Daegu Haany University, Republic of Korea. \\ ${ }^{5}$ Department of Preventive Medicine, College of Korean Medicine, Daegu Haany University, Republic of Korea.
}

Objectives: We examined the effects of a mixed formula consisting of dried pomegranate concentrate powder (PCP) and the aqueous extracts of Eucommiae cortex (EC) and Achyranthis radix (AR) in rats with surgically induced osteoarthritis (OA). Methods: Two weeks after OA-inducing surgery, a PCP:EC:AR 5:4:1 $(\mathrm{g} / \mathrm{g})$ combination or single formula was orally administered. Changes in body weight, knee thickness, maximum knee extension angle, bone mineral density of the knee joints, femoral and tibial articular surfaces, and compressive strength of the femoral and tibial articular cartilage (AC) were assessed, along with the prostaglandin E2 level, 5-lipoxygenase, matrix metalloproteinase (MMP)-2 and MMP-9 activity, and chondrogenic gene mRNA expression in the femoral and tibial AC with the synovial membrane (SM). In addition, the number of cleaved poly(ADP-ribose) polymerase, cyclooxygenase and tumor necrosis factor- $\alpha$-immunoreactive cells in the femoral and tibial AC with SM were monitored, and the rate of cell proliferation was determined with a 5-bromo-2'-deoxyuridine uptake assay.

Results : The signs of surgically induced OA in rats were significantly inhibited by both PCP, EC and AR combined and single formulas. In particular, the combination formula-treated OA model rats showed dose-dependent, significantly increased inhibitory activity against all tested criteria compared with single formula-treated rats.

Conclusions: Taken together, our results suggest that the combination formula synergistically increased the anti-OA effects of its components through anti-inflammatory and chondrogenic activity in rats with surgically induced OA. In addition, 200,100 and $50 \mathrm{mg} / \mathrm{kg}$ combination formula treatments showed dose-dependent inhibitory activity against all of the tested criteria.

Key Words : Dried pomegranate concentrate powder, Eucommiae Cortex, Achyranthis Radix, PCP:EC:AR 5:4:1 (g/g) mixed formulation, Efficacy confirmation, Surgically induced osteoarthritic rats

\footnotetext{
- Received: 16 August 2018 - Revised : 12 December 2018 Accepted : 12 December 2018

- These authors contributed equally to this work.

- Correspondence to : Young-Joon Lee

Department of Preventive medicine, College of Korean Medicine, Daegu Haany University

1 Haanydaero, Gyeongsan, Gyeongsangbuk-Do, 38610, Republic of Korea

Tel : +82-53-819-1296, Fax : +82-53-819-1576, E-mail : gksxntk@dhu.ac.kr

- Correspondence to : Ki-Moon Park

Department of Foodscience and biotechnology, Sungkyunkwan University

2066 Seoburo, Jangan-gu, Suwon, Gyeonggi-do, 16419, Republic of Korea.

Tel : +82-31-290-7806, E-mail : Pkm1001@skku.edu
} 


\section{Introduction}

Osteoarthritis (OA) occurs when the function and structure of articulation is altered by age and injury; it is the most common joint disease in the elderly ${ }^{1)}$. Aging is considered an important factor in the development of OA because the inevitable repetitive loading or injury of articular cartilage (AC) leads to increased regeneration, which consequently causes cartilage degeneration ${ }^{2}$. The expression of pro-inflammatory cytokines, such as interleukin (IL)-1, IL-6, IL-18 and tumor necrosis factor- $\alpha(\mathrm{TNF}-\alpha)$ increase proportionally with age; they stimulate cartilage resorption and inhibit the synthesis of new matrix components in articular tissue ${ }^{3-5)}$. These inflammatory OA pathways can be induced by impaired autophagy, oxidative stress, failure to clear apoptotic bodies and protein misfolding ${ }^{3-5)}$.

$\mathrm{AC}$ is a complex structure composed of chondrocytes and the extracellular matrix (ECM), including collagen, proteoglycans (PGs), aggrecan and SRY-box 9 $(\mathrm{SOX} 9)^{6), 7)}$. Changes in the ECM induce the pathogenesis of OA. Once AC is damaged by physical forces, it loses PGs and undergoes swelling and hypertrophy. When chondrocytes recognize changes in the ECM to synthesize matrix molecules, chondrocytes increase and produce nitric oxide, which activates cytokines $^{8)}$. In addition, IL-1 and TNF- $\alpha$ stimulate the production of prostaglandin E2 $\left(\mathrm{PGE}_{2}\right)$ by inducing the expression of cyclooxygenase-2 (COX-2) and soluble phospholipase $\mathrm{A}_{2}{ }^{9}$. As the balance between the synthesis and degradation of chondrocytes is an important factor in the maintenance of $\mathrm{AC}$, the disruption of this process results in the progressive thinning of the $\mathrm{AC}^{10)}$. The expression of matrix metalloproteinases (MMPs) also participates in the degradation of collagens, and ultimately, the disruption of fibril function ${ }^{11)}$. The thinning and destruction of the $\mathrm{AC}$ results in the clinical symptoms of joint pain and loss of joint function ${ }^{8), 9 \text { ) }}$.

Because the number of older people is increasing worldwide, the prevalence of $\mathrm{OA}$ is expected to increase. Thus, there is an urgent need to develop disease-modifying OA drugs for patients suffering from $\mathrm{OA}^{12)}$. Nonsteroidal anti-inflammatory drugs (NSAIDs), analgesics, and hyaluronic acid have been used to slow the progression of OA, but have no overt disease-modifying effects ${ }^{2}$. NSAIDs may even exacerbate the progression of $\mathrm{OA}$, and these effects are likely due to the suppression of the synthesis of PG, a key component in the formation and function of cartilage ${ }^{2)}$. Our group has been exploring agents with protective effects against $\mathrm{OA}^{6,77,13)}$, including natural products, medicinal foods and mixed formulations, to determine whether they exhibit potent anti-arthritic effects.

Pomegranates have a high fiber, pectin and tannin content ${ }^{14)}$, and contain flavonoids and anthocyanins in their seed oil and juice. Furthermore, powerful antioxidant and anti-inflammatory effects of pomegranate on chondrocytes have been identified ${ }^{15-18)}$; our previous studies demonstrated that pomegranate has various biological activities such as antioxidant and anti-inflammatory effects ${ }^{19-22)}$. These protective effects have caused pomegranate products to become increasingly popular worldwide. Eucommiae cortex (EC) has been used in the protection of the liver and kidneys, and the treatment of hypertension, inflammation and viral infection in traditional Korean medicine ${ }^{23-25)}$. In particular, EC as a component of a mixture has been demonstrated to promote anti-arthritic properties ${ }^{26), 27)}$. Achyranthis radix (AR) has been used extensively in the treatment of osteodynia of the lumbar region and knees, as well as flaccidity and spasms of the limbs ${ }^{28)}$. Several previous studies have demonstrated the anti-arthritic properties of AR through in vivo and 
in vitro experiments ${ }^{29), 30)}$.

As mixed formulations of medicinal agents may have synergistic biological activity from the diversity of their ingredients ${ }^{19), 31-34)}$, we expected that appropriately mixed formulations of pomegranate concentrate powder (PCP), EC and AR could be potent alternative agents to treat OA. The results of our previous in vitro study ${ }^{35)}$ suggested that a mixed formulation of PCP with appropriate proportions of $\mathrm{EC}$ and $\mathrm{AR}$ induced potent synergistic effects. Based on these results, an in vivo study was performed to select the appropriate proportions among the nine types of formulations consisting of PCP with AR and EC. As a result, a PCP:AR:EC 5:4:1 (g/g) combination was selected as the best, showing evident synergistic anti-OA potential compared with equal dosages of each single formula $(\mathrm{PCP}, \mathrm{EC} \text { or } \mathrm{AR})^{36)}$. However, the previous in vivo study was insufficient to obtain information regarding the PCP:AR:EC 5:4:1 (g/g) combination because the objective was focused on determining the appropriate proportion of the treatments. Thus, this study examined the dose-dependent effects of several doses of the PCP:AR:EC 5:4:1 $(\mathrm{g} / \mathrm{g})$ combination in rats with surgically induced OA through an anterior cruciate ligament transection and partial medial meniscectomy. The expression levels of $\mathrm{PGE}_{2}$, 5-lipoxygenase (LPO), MMP-2, and MMP-9 were observed in rats with surgically induced OA concomitant with the transcript levels of chondrogenic genes. Knee thickness and the maximum extension angles of each knee were analyzed, along with the numbers of cleaved poly(ADP-ribose) polymerase (PARP), COX-2 and TNF- $\alpha$ -immunoreactive cells in the femoral and tibial AC with the synovial membrane (SM).

\section{Materials and methods}

\section{Animals and husbandry}

A total of 105 healthy male SPF/VAF outbred rats and Crl:CD1[Sprague-Dawley] rats (6-week old, 150 180 g upon receipt; OrientBio, Seungnam, Korea) were used after acclimatization for 8 days. The rats were maintained at $20-25^{\circ} \mathrm{C}$ and $45-55 \%$ humidity. The light:dark cycle was 12L:12D; feed and water were supplied ad libitum. Ninety rats underwent the surgical induction of $\mathrm{OA}$, in the following treatment groups: OA control (orally administered distilled water), diclofenac group (2 $\mathrm{mg} / \mathrm{kg}$ subcutaneous diclofenac sodium), PCP group (orally administered $200 \mathrm{mg} / \mathrm{kg}$ PCP), EC group (orally administered $200 \mathrm{mg} / \mathrm{kg} \mathrm{EC),}$ AR group (orally administered $200 \mathrm{mg} / \mathrm{kg} \mathrm{AR}$ ), 200 $\mathrm{mg} / \mathrm{kg}$ group (orally administered $200 \mathrm{mg} / \mathrm{kg}$ PCP:EC:AR mixed formula), $100 \mathrm{mg} / \mathrm{kg}$ group (orally administered $100 \mathrm{mg} / \mathrm{kg}$ PCP:EC:AR mixed formula) and $50 \mathrm{mg} / \mathrm{kg}$ group (orally administered $50 \mathrm{mg} / \mathrm{kg}$ PCP:EC:AR mixed formula). 15 rats were sham-operated control rats, receiving orally administered distilled water. All of the laboratory animals were treated according to internationally accepted regulations.

Approval by the Institutional Animal Care and Use Committee of Daegu Haany University (Gyeongsan, Gyeongbuk, Korea) was obtained prior to all animal experiments [Approval No., DHU2015-051].

\section{Preparation and administration of test substances}

PCP contained the active ingredient, $1.15 \mathrm{mg} / \mathrm{g}$ ellagic acid. The EC extracts (containing $1.62 \mathrm{mg} / \mathrm{g}$ pinoresinol diglucoside) and AR extracts (containing $0.25 \mathrm{mg} / \mathrm{g}$ ecdysterone) were prepared and supplied by HL Science Co., Ltd. (Uiwang-si, Gyeonggi-do, Korea). All test materials were stored at $4^{\circ} \mathrm{C}$ and protected against light and moisture. A dose level of 
$200 \mathrm{mg} / \mathrm{kg}$ was selected as the highest dose of the mixed formula consisting of PCP:EC:AR 5:4:1 (g/g) as requested by the sponsor based on the highest possible clinical dosage in humans. The 100 and $50 \mathrm{mg} / \mathrm{kg}$ doses were selected as the middle and lowest doses by reducing the initial dose by a factor of 2 . The doses of each single herbal extract (PCP, EC and AR) were also administered at $200 \mathrm{mg} / \mathrm{kg}$ to directly compare the potential synergistic effects with the mixed formula.

The PCP:EC:AR 5:4:1 (g/g) mixed formula at doses of 200,100 , and $50 \mathrm{mg} / \mathrm{kg}$, or $200 \mathrm{mg} / \mathrm{kg}$ PCP, EC or $\mathrm{AR}$ were dissolved in distilled water at $5 \mathrm{~mL} / \mathrm{kg}$ and orally administered once daily for 58 days beginning 2 weeks after OA surgery. $2 \mathrm{mg}$ diclofenac was dissolved in $5 \mathrm{~mL}$ sterile saline and subcutaneously administered on the dorsal back skin at a volume of $5 \mathrm{~mL} / \mathrm{kg}$, equivalent to $2 \mathrm{mg} / \mathrm{kg}$, daily for 58 days beginning 14 days after OA surgery. Each single formula of PCP, $\mathrm{EC}$ and $\mathrm{AR}$ was prepared by dissolving $200 \mathrm{mg}$ in $5 \mathrm{~mL}$ distilled water, after which it was orally administered in a volume of $5 \mathrm{~mL} / \mathrm{kg}$, equivalent to $200 \mathrm{mg} / \mathrm{kg}$, as in our previous study ${ }^{36}$. The PCP:EC:AR 5:4:1 (g/g) mixed formula was prepared by directly dissolving 100, 80 and $20 \mathrm{mg}$ PCP, EC and AR in $5 \mathrm{~mL}$ distilled water for the highest dosage; 50, 40 and $10 \mathrm{mg}$ for the middle dosage, or 25,20 , and 5 $\mathrm{mg}$ for the lowest dosage; this was orally administered in a volume of $5 \mathrm{~mL} / \mathrm{kg}$, equivalent to 200,100 , and $50 \mathrm{mg} / \mathrm{kg}$, respectively. Equal volumes of vehicle (distilled water) were orally administered to the sham and OA control rats. Formulations of test substances were prepared weekly and stored at $4^{\circ} \mathrm{C}$ until use.

\section{OA induction by anterior cruciate ligament transection and partial medial meniscectomy}

Ten rats per group were allocated (selected) according to variations in body weight and knee thickness at 6 days after OA surgery. Isoflurane (2-3\% for induction, $1-1.5 \%$ for maintenance; Hana Pharm. Co., Hwasung, Korea) in a mixture of $\mathrm{N}_{2} \mathrm{O}$ and $\mathrm{O}_{2}$ was used for anesthesia with an inhalation anesthesia apparatus (Surgivet, Waukesha, WI, USA) and a ventilator (Model 687, Harvard Apparatus, Cambridge, UK). The OA induction group received surgery including anterior cruciate ligament transection and partial medial meniscectomy through an incision on the medial aspect of the joint capsule, in front of the medial collateral ligament. Then the incision was sutured in two layers. The joint capsule was closed separately from the peripheral tissue using dissolving 5-0 Vicryl sutures, and the skin was closed with interrupted silk sutures. The operated side was used as OA induced side; the other side (non-operated, intact side) was designated as the contralateral side. A similar operation was performed in the sham operated group, except for the anterior cruciate ligament transection and partial medial meniscectomy, according to the method described above $^{34), 37-39)}$

\section{Body weight measurements}

The body weights of rats were recorded once per week using an electronic balance. The rats were sacrificed at $24 \mathrm{~h}$ after the last administration of treatment. Rats were fasted overnight for $\sim 18 \mathrm{~h}$ prior to surgery for reducing the risk of the anaesthesia-related pulmonary aspiration ${ }^{40-42)}$, but were provided with free access to water.

\section{Measurements of knee thickness}

At 6 days after the surgical induction of OA, on the day of initial administration, and at 1, 7, 14, 21, $28,35,42,49,57$ and 58 days after treatment, the knee thickness was observed in the OA-operated hind knees using digital calipers (Mytutoyo, Tokyo, Japan) with the joint capsule exposed to minimize the 
differences from surrounding tissues. Knee thickness was also measured at sacrifice.

\section{Determination of the maximum extension angle of the knees}

After sacrifice, the region between the coxofemoral joint and ankle was dissected in OA-induced knees, while the intact articular capsule was excluded. Following dissection, each knee was examined to determine the maximum extension angle, as described in previous methods ${ }^{34), 37-39), 43)}$. Angle $0^{\circ}$ corresponds to the fullest possible extension. To reduce bias in the operations and measurements, the same veterinarian examined the extension levels for all rats.

\section{Measurement of focal bone mineral density (BMD)}

The mean focal BMD of the OA or sham-operated total knee joints, and femoral and tibial articular surfaces were detected by live dual-energy X-ray absorptiometry (DEXA; InAly zer, Medikors, Seungnam, Korea; $\left.\mathrm{g} / \mathrm{cm}^{2}\right)$.

\section{Measurement of CS}

Focal CS was detected on the femoral and tibial articular surfaces of the rats by Newton (SV-H1000, Japan Instrumentation System Co., Tokyo, Japan).

Preparation of femoral and tibial AC with SM tissue homogenates

Tissue homogenates were obtained from the femoral and tibial $\mathrm{AC}$ with $\mathrm{SM}$ using an ultrasonic cell disruptor (Model KS-750, Madell Technology Corp., Ontario, CA, USA). Tissue homogenates were centrifuged at $21,000 \times \mathrm{g}$, and separated supernatants were used to detect PGE $_{2}$ levels and 5-LPO, MMP-2 and MMP-9 activity

\section{Determination of $\mathrm{PGE}_{2}$ levels}

The $\mathrm{PGE}_{2}$ levels were determined using a $\mathrm{PGE}_{2}$ assay kit (R\&D Systems, Minneapolis, MN, USA) with the supernatants obtained from the femoral and tibial AC with SM. The optical densities were read at $540 \mathrm{~nm}$ with a microplate reader (Sunrise; Tecan, Männedorf, Switzerland; $\mathrm{pg} / \mathrm{mL}$ ), according to the manufacturer's instructions.

\section{5-LPO activity assay}

5-LPO levels were determined using a Lipoxygenase Inhibitor Screening Assay kit was acquired from Cayman Chemical Company (Ann Arbor, MI, USA) with the supernatants obtained from the femoral and tibial AC with SM. The optical densities were read at $490 \mathrm{~nm}$ with a microplate reader $(\mu \mathrm{M} / \mathrm{min} / \mathrm{mL})$, according to the manufacturer's instructions.

\section{MMP inhibitory assay}

MMP-2 and MMP-9 activity were separately measured in the supernatants of femoral and tibial AC with SM tissue homogenates using a commercial MMP ELISA kit (Mybiosource, San Diego, CA, USA). Optical density was read as $560 \mathrm{~nm}(\mathrm{ng} / \mathrm{mL})$ using a microplate reader, according to the manufacturer's protocol.

Reverse transcription-quantitative polymerase chain reaction ( $R T-q P C R$ ) analysis of ECM-related chondrogenic gene mRNA expression

Collagen type II, SOX9, and aggrecan mRNA expression levels in prepared femoral and tibial AC and in the SM homogenates were detected separately by RT-qPCR according to previously established methods ${ }^{44), 45)}$. Briefly, RNA extraction was performed with TRIzol reagent, as per the method described in 
Anti-osteoarthritic effects of a combination of pomegranate concentrate powder, Eucommiae cortex and Achyranthis radix in rats

previous studies ${ }^{7), 13)}$. The concentration of the RNA samples were analyzed using the CFX96 ${ }^{\mathrm{TM}}$ Real-Time System (Bio-Rad, Hercules, CA, USA). To obtain RNA with high integrity, recombinant DNase I (DNA-free; Ambion, Austin, TX, USA) was used for the removal of DNA contamination. The reverse transcription of RNA was conducted with the High-Capacity cDNA Reverse Transcription Kit (Applied Biosystems, Foster City, CA, USA) according to the manufacturer's protocols. The amplification of cDNA by PCR was conducted as follows: $58^{\circ} \mathrm{C}$ for $30 \mathrm{~min}, 94^{\circ} \mathrm{C}$ for $2 \mathrm{~min}$, 35 cycles of $94^{\circ} \mathrm{C}$ for $15 \mathrm{sec}, 60^{\circ} \mathrm{C}$ for $30 \mathrm{sec}, 68^{\circ} \mathrm{C}$ for $1 \mathrm{~min}$, and $72^{\circ} \mathrm{C}$ for $5 \mathrm{~min}$. Analyses were performed using the ABI Step One Plus Sequence Detection System (Applied Biosystems, Foster City, CA, USA). Transcript levels were expressed as relative to the vehicle control. The mRNA level of $\beta$-actin was used as a loading control. Primer sequences were as follows: Collagen type II, 5'-GAGTGGAAGAGCGGAGACTACTG-3' and 5'CTCCATGTTGCAGAAGACTTTCA-3'; SOX-9, 5'-AGAGCGTTGCTCGGAACTGT-3', and 5'-TCCTGGACCGAAACTGGTAAA-3'; Aggrecan, 5'-GATGTCCCCTGCAATTACCA-3' and 5'-TCTGTGCAAGTGATTCGAGG-3'; $\beta$-actin, 5'-ATCGTGGGCCGCCCTAGGCA-3' and 5'-TGGCCTTAGGGTtCAGAGGGG-3'. The relative expression of collagen type II, SOX-9 and aggrecan was calculated using the $2^{-\Delta \Delta \mathrm{Cq}}$ method $^{46)}$.

\section{5-bromo-2'-deoxyuridine uptake (BrdU) proliferation assay}

To examine the effects of the test substances on the proliferation of cells, a BrdU assay was performed within the rat knee joints. The rats were intraperitoneally injected with BrdU (Sigma-Aldrich, St. Louise, MO, USA) at $72 \mathrm{~h}$ prior to sacrifice ${ }^{39), 47)}$. BrdU uptake was detected by immunohistochemistry using an anti-BrdU antibody, as described previously ${ }^{34), 37), 38)}$, for the femoral and tibial AC and SM.

\section{Histology}

Samples were taken from the knee joints, including the joint capsules, and immersed in $10 \%$ neutral-buffered formalin for fixation. Next, the samples were decalcified using a decalcifying solution for 5 days. The sections from each knee joint were longitudinally trimmed, paraffin-embedded, serially sectioned (3-4 $\mu \mathrm{m})$. In order to reduce interpretation bias, blinded histological assessments were conducted using a light microscope.

\section{Immunohistochemistry}

Corresponding purified primary antibodies were used to determine the immunoreactivity levels for the apoptotic marker PARP (Cell Signaling Technology Inc, Danvers, MA, USA, 9545) and the proinflammatory cytokines TNF- $\alpha$ (Santa Cruz Biotechnology, Santa Cruz, CA, USA, sc-52746) and COX-2 (Cayman Chemical., Ann Arbor, MI, USA, 160126), using an avidin-biotin-peroxidase complex $(\mathrm{ABC})$ and a peroxidase substrate kit (Vector Labs, Burlingame, CA, USA) for the femoral and tibial $\mathrm{AC}$ and SM tissues. Briefly, samples were incubated with methanol with $0.3 \% \mathrm{H}_{2} \mathrm{O}_{2}$ for 30 min to block endogenous peroxidase activity. The samples were then incubated with normal horse serum solution for $1 \mathrm{~h}$ to block non-specific immunoglobulin binding. The sections were incubated with the primary antibody at $4^{\circ} \mathrm{C}$ in a humidified chamber, then the biotinylated universal secondary antibody and $\mathrm{ABC}$ solutions were added at $18-25^{\circ} \mathrm{C}$ in the humidified chamber. Finally a peroxidase substrate kit was added for $3 \mathrm{~min}$ at $18-25^{\circ} \mathrm{C}$, and the sections were washed three times in $0.01 \mathrm{M}$ PBS for 10 min each.

\section{Histomorphometry}

The Mankin score was used to evaluate the femoral and tibial AC damages using the Safranin-O stain, as 
previously recommended by a number of researchers ${ }^{34), 37-39)}$. A high score represents a high level of OA (Semiquantative scores; Max = 12). All histological analyses were performed by the same pathologist, who was blinded to the group distributions. In addition, the thicknesses of the tibial and femoral AC ( $\mu \mathrm{m} /$ cartilage), the epithelial lining thickness of the SM ( $\mu \mathrm{m} / \mathrm{knee}$ joint) and the number of inflammatory cells infiltrating the SM (cells $/ \mathrm{mm}^{2}$ ) were measured in longitudinally prepared and trimmed samples using automated image analyzer software (iSolution FL ver 9.1, IMT i-solution Inc., Vancouver, Quebec, Canada), according to our previously established methods ${ }^{34,37-39)}$. Samples were considered positive if $>20 \%$ of the cells were immunoreactive to the BrdU, PARP, TNF- $\alpha$ or COX-2 antibodies as determined using an automated digital image analyzer (cells $/ \mathrm{mm}^{2}$ ).

\section{Statistical analyses}

Data is shown as the mean \pm SD of 10 rats. Differences between groups were tested using multiple comparison tests. The Levene test was performed for homogeneity of variance. Where there were no significant deviations from homogeneity of variance, the data were analyzed by a one-way analysis of variance followed by a least-significant difference (LSD) multiple comparison test to determine which pairs were significantly different. In cases of significant deviations from homogeneity of variance, the non-parametric Kruskal-Wallis H test was conducted instead; where significant differences were determined in the Kruskal-Wallis H test, the Mann-Whitney U test (MW) with Bonferroni's correction was performed to determine the intergroup difference. SPSS software (SPSS Inc., Chicago,IL, USA) was used for all statistical data analyses. $\mathrm{P}<0.05$ was regarded as statistically significant.

\section{Results}

\section{Changes in body weight}

Ten rats were chosen for each group with distributed body weights at 6 days after OA induction; there were no significant differences in initial body weight between the rat groups. None of the PCP:EC:AR 5:4:1 (g/g) mixed formula-administrated groups displayed significant changes in body weight compared with those of the PCP, EC and AR single formula-administrated group throughout the experiment (Fig 1).

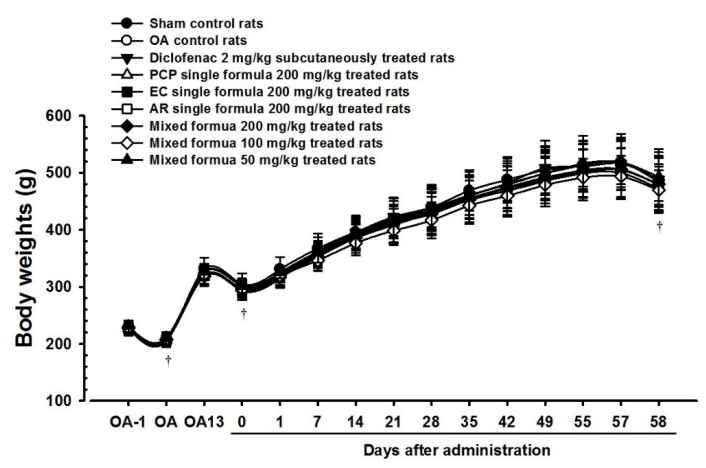

Fig. 1. Effect of mixed formulation (Pomegranate Concentration Powder (PCP): Aqueous extracts of Eucommiae Cortex (EC): Aqueous extracts Achyranthis Radix (AR) 5:4:1 $(\mathrm{g} / \mathrm{g})$ ) on changes of body weight of surgically induced osteoarthritis (OA). The data are shown as mean \pm S.D. of 10 rats, $g$.

\section{Changes in knee thickness}

Significant increases in knee thickness were observed in OA control rats compared with sham control rats. OA-induced knee thickness significantly decreased after treatment with 200,100 or $50 \mathrm{mg} / \mathrm{kg}$ PCP:EC:AR 5:4:1 (g/g) mixed formula. In particular, 200 and $100 \mathrm{mg} / \mathrm{kg}$ PCP:EC:AR 5:4:1 (g/g) mixed formula-treated rats dose-dependently decreased knee thickness compared with PCP, EC or AR single formula-treated rats from 1 day after initial administration. The $50 \mathrm{mg} / \mathrm{kg}$ PCP:EC:AR 5:4:1 (g/g) mixed formula induced significant decreases in knee thickness after 7 days (Fig 2). 


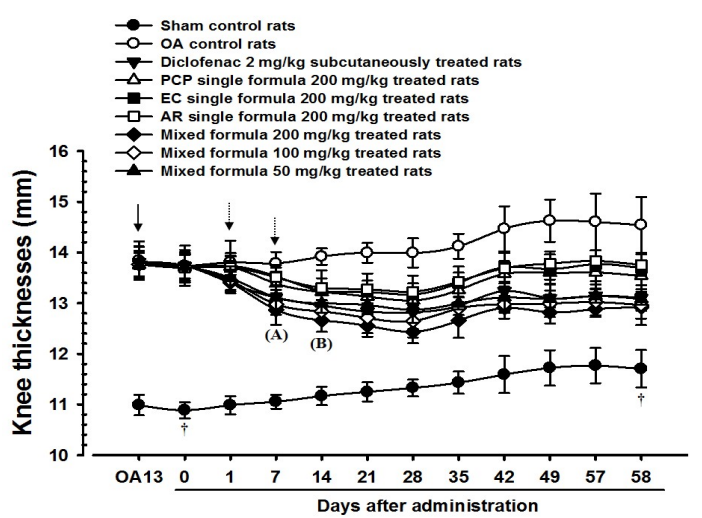

Fig. 2. Effect of mixed formulation (Pomegranate Concentration Powder (PCP): Aqueous extracts of Eucommiae Cortex (EC): Aqueous extracts Achyranthis Radix (AR) 5:4:1 (g/g)) on knee thickness changes of surgically induced osteoarthritis (OA). Significant $(p<0.01)$ increases of knee thicknesses were demonstrated in OA control rats as compared with sham control rats in the present study (arrow). Significant $(p<0.01)$ decreases of knee thicknesses were demonstrated in diclofenac, PCP: EC:AR 5:4:1 (g/g) mixed formula 200 and $100 \mathrm{mg} / \mathrm{kg}$ treated rats as compared with OA control rats, and in PCP, AR and EC single formula $200 \mathrm{mg} / \mathrm{kg}$, PCP:EC:AR 5:4:1 (g/g) mixed formula $50 \mathrm{mg} / \mathrm{kg}$ treated rats as compared with OA control rats, respectively (dot arrows). Values are expressed mean \pm S.D. of 10 rats, $\mathrm{mm}$.

\section{Effects on knee thickness after capsule exposure}

Significant increases in capsule-exposed knee thickness were detected in OA control rats compared with sham control rats. However, significant decreases in knee thickness after capsule exposure were observed in all test substance-treated rat groups, including the PCP single formula-treated OA rats compared to OA control rats. The 200, 100 and $50 \mathrm{mg} / \mathrm{kg}$ PCP:EC:AR 5:4:1 (g/g) formula groups also showed dose-dependent decreases in capsule-exposed knee thickness compared with each PCP, EC, and AR single treatment group (Fig 3).

\section{Effects on maximum knee extension angle}

Significant increases in maximum knee extension

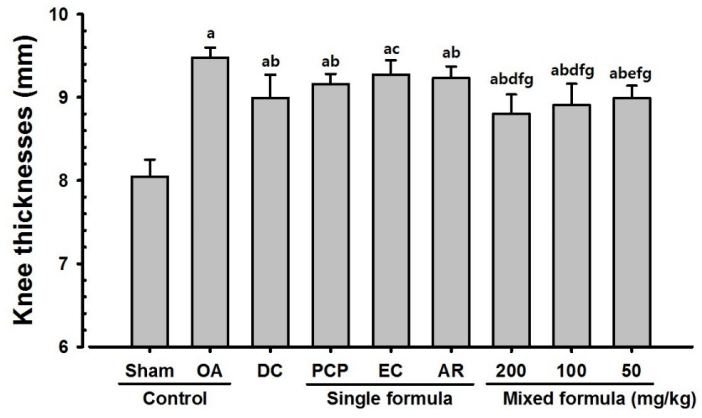

Fig. 3. Effect of mixed formulation (Pomegranate Concentration Powder (PCP): Aqueous extracts of Eucommiae Cortex (EC): Aqueous extracts Achyranthis Radix (AR) 5:4:1 (g/g)) on knee thickness changes after capsule exposure of surgically induced osteoarthritis (OA). ${ }^{a} p<0.01$, compared to the sham control; ${ }^{b} p<0.01$ and ${ }^{c} p<0.05$, compared to the OA control; ${ }^{d} p<0.01$ and ${ }^{e}$ $p<0.05$, compared to the PCP only; ${ }^{f} p<0.01$, compared to the EC only; ${ }^{g} p\langle 0.01$, compared to the AR only.

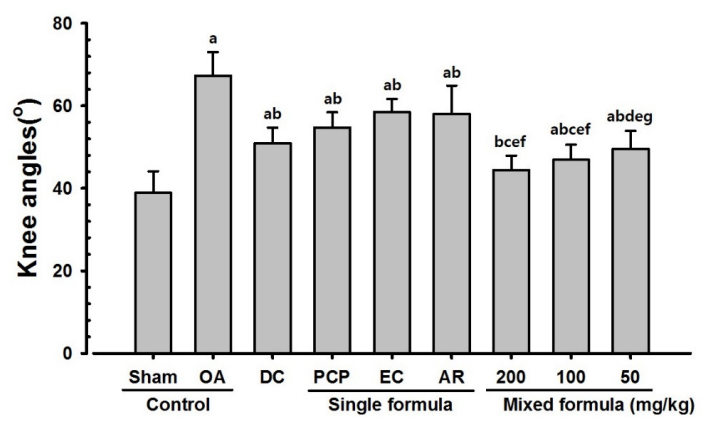

Fig. 4. Effect of mixed formulation (Pomegranate Concentration Powder (PCP): Aqueous extracts of Aqueous extracts of Eucommiae Cortex (EC): Aqueous extracts Achyranthis Radix (AR) 5:4:1 (g/g)) on knee extension angles of surgically induced osteoarthritis (OA). ${ }^{a} p\left\langle 0.01\right.$, compared to the sham control; ${ }^{b} p\langle 0.01$, compared to the OA control; and ${ }^{\mathrm{c}} p<0.05$ and ${ }^{\mathrm{d}} p<0.01$, compared to the PCP only; ${ }^{\mathrm{p}} \mathrm{p}\left\langle 0.01\right.$, compared to the EC only; ${ }^{\mathrm{f}}$ $p<0.01$ and $g$ p $<0.05$, compared to the AR only.

angle were observed in the OA control rats compared to sham control rats; however, these angles were significantly decreased in response to 200,100, and $50 \mathrm{mg} / \mathrm{kg}$ PCP:EC:AR 5:4:1 (g/g) compared with those of OA control rats. In particular, the 200, 100, and 
$50 \mathrm{mg} / \mathrm{kg}$ PCP:EC:AR 5:4:1 (g/g) combination treated rats also showed dose-dependent decreases in maximum knee extension angle compared with each single formula group (Fig 4).

\section{Effects on DEXA images and BMD}

Noticeable OA-related signs were identified in the $\mathrm{X}$-ray images of OA control rats, including loss of the knee joint region, femoral and tibial $\mathrm{AC}$ erosion and osteophyte formation. In addition, significant corresponding decreases in the focal BMD of the total knee joint, as well as the femoral and tibial articular surface regions, were observed in OA control rats compared with the sham control rats. However, notable decreases in OA-like X-ray signs and corresponding increases in the total knee joint, and femoral and tibial articular surface BMDs were observed in all of the test substance-treated rats, including the AR single formula-treated OA rats compared to OA control rats. In particular, the 200,100 and $50 \mathrm{mg} / \mathrm{kg}$ combination treatment groups showed dose-dependent inhibition of OA-like X-ray signs, and significant increases in total knee joint, and femoral and tibial articular surface focal
BMDs compared with groups treated with PCP, EC or AR alone (Table 1 and Fig 5).

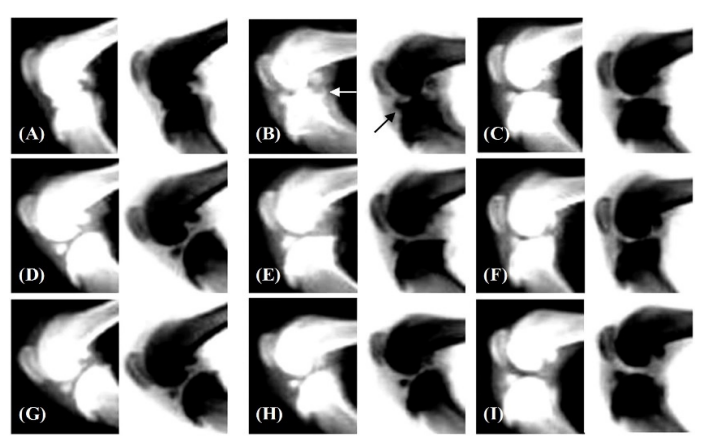

Fig. 5. Representative DEXA images of the knee joints, taken from sham-operated or OA rats. Noticeable OA-related $X$-ray images including loss of the knee joint region, the femur and tibia $A C$ erosion, and osteophyte formations (arrows) were observed in OA control rats DEXA image analysis as compared with sham control rats, respectively. (A), Sham vehicle control; (B), OA control; (C), OA-surgery+ diclofenac sodium $2 \mathrm{mg} / \mathrm{kg}$ subcutaneously; (D), OA-surgery+ $200 \mathrm{mg} / \mathrm{kg}$ PCP only; (E), OA-surgery+200 mg/kg EC only; (F), OA-surgery+200 $\mathrm{mg} / \mathrm{kg}$ AR only; (G), $200 \mathrm{mg} / \mathrm{kg}$ PCP:EC:AR 5:4:1 (g/g); (H), $100 \mathrm{mg} / \mathrm{kg}$ PCP:EC:AR 5:4:1 (g/g) mixed formula; (I), $50 \mathrm{mg} / \mathrm{kg}$ PCP:EC:AR 5:4:1 (g/g) mixed formula. AR = Aqueous extracts of Achyranthis Radix, OA = Osteoarthritis; $\mathrm{EC}=$ Aqueous extracts of Eucommiae Cortex, $\mathrm{PCP}=$ Pomegranate Concentration Powder; DEXA = Dual-energy $\mathrm{x}$-ray absorptionmetry; $\mathrm{AC}=$ Articular cartilage.

Table 1. Effects of PCP:EC:AR 5:4:1 (g/g) Mixed Formula on Focal BMD

\begin{tabular}{|c|c|c|c|}
\hline Items & & Focal BMD & \\
\hline Groups & Total knee joint & Femur articular surface & Tibia articular surface \\
\hline \multicolumn{4}{|l|}{ Controls } \\
\hline Sham & $0.0567 \pm 0.0028$ & $0.0583 \pm 0.0032$ & $0.0597 \pm 0.0030$ \\
\hline $\mathrm{OA}$ & $0.0437 \pm 0.0020^{\mathrm{a}}$ & $0.0440 \pm 0.0019^{\mathrm{a}}$ & $0.0449 \pm 0.0019^{\mathrm{a}}$ \\
\hline Diclofenac & $0.0506 \pm 0.0023^{\mathrm{ab}}$ & $0.0506 \pm 0.0022^{a b}$ & $0.0508 \pm 0.0028^{\mathrm{ab}}$ \\
\hline \multicolumn{4}{|c|}{ Single formula $(200 \mathrm{mg} / \mathrm{kg})$} \\
\hline PCP & $0.0482 \pm 0.0013^{\mathrm{ab}}$ & $0.0486 \pm 0.0016^{\mathrm{ab}}$ & $0.0484 \pm 0.0017^{\mathrm{ab}}$ \\
\hline $\mathrm{EC}$ & $0.0476 \pm 0.0019^{\mathrm{ab}}$ & $0.0477 \pm 0.0026^{\mathrm{ab}}$ & $0.0479 \pm 0.0013^{\mathrm{ab}}$ \\
\hline $\mathrm{AR}$ & $0.0477 \pm 0.0018^{\mathrm{ab}}$ & $0.0480 \pm 0.0021^{\mathrm{ab}}$ & $0.0483 \pm 0.0016^{\mathrm{ab}}$ \\
\hline \multicolumn{4}{|c|}{ Mixed formula - PCP:EC:AR 5:4:1 (g/g) } \\
\hline $200 \mathrm{mg} / \mathrm{kg}$ & $0.0531 \pm 0.0017^{\text {abcef }}$ & $0.0547 \pm 0.0023^{\text {abcef }}$ & $0.0548 \pm 0.0034^{\text {abcef }}$ \\
\hline $100 \mathrm{mg} / \mathrm{kg}$ & $0.0521 \pm 0.0019^{\text {abcef }}$ & $0.0528 \pm 0.0010^{\text {abcef }}$ & $0.0534 \pm 0.0016^{\text {abcef }}$ \\
\hline $50 \mathrm{mg} / \mathrm{kg}$ & $0.0503 \pm 0.0024^{\text {abdef }}$ & $0.0509 \pm 0.0013^{\text {abdef }}$ & $0.0509 \pm 0.0021^{\text {abcef }}$ \\
\hline
\end{tabular}

Data are shown as mean \pm SD of 10 rats, $\mathrm{g} / \mathrm{cm}^{2}$. BMD, Bone mineral density; OA, Osteoarthritis; PCP, Pomegranate Concentration Powder; EC, Aqueous extracts of Eucommiae Cortex; AR, Aqueous extracts of Achyranthis Radix. ${ }^{a} \mathrm{p}<0.01$, compared to the sham control; ${ }^{\mathrm{b}} \mathrm{p}<0.01$, compared to the OA control; ${ }^{\mathrm{c}} \mathrm{p}<0.01$ and ${ }^{\mathrm{d}} \mathrm{p}<0.05$, compared to the PCP only; ${ }^{\mathrm{e}} \mathrm{p}<0.01$, compared to the EC only; ${ }^{\mathrm{f}} \mathrm{p}<0.01$, compared to the AR only. 


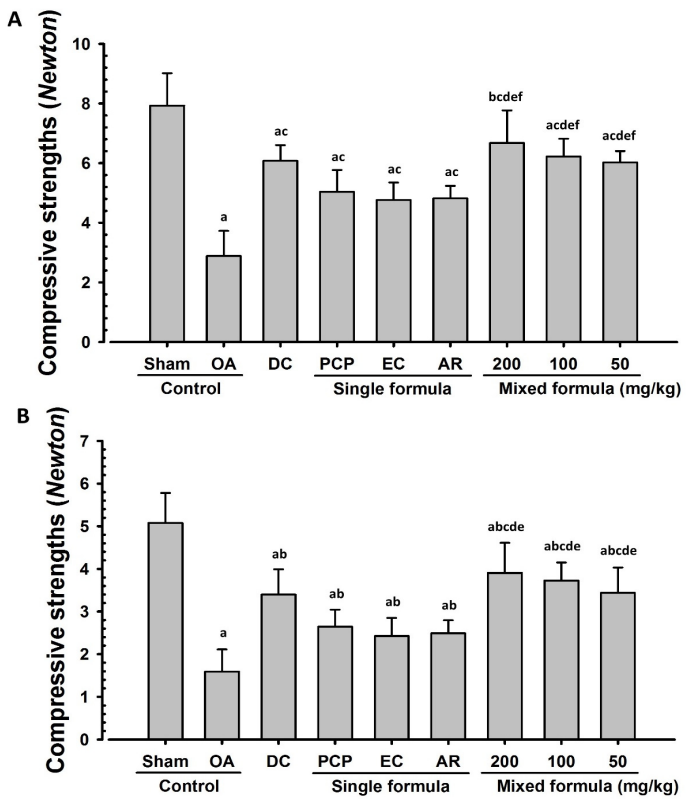

Fig. 6. Effect of mixed formulation (Pomegranate Concentration Powder (PCP): Aqueous extracts of Eucommiae Cortex (EC): Aqueous extracts Achyranthis Radix (AR) 5:4:1 (g/g) on Focal Compressive strength (CS) of the femur and tibia AC (Articular cartilage) in surgically induced osteoarthritis (OA). (A) femur, (B) tibia; ${ }^{a} p<0.01$ and ${ }^{b} p<0.05$, compared to the sham control; ${ }^{c} p<0.01$, compared to the OA control; ${ }^{d} p<0.01$, compared to the PCP only; ${ }^{e} p<0.01$, compared to the EC only; ${ }^{f} p<0.01$, compared to the AR only.
Effects on the CS of the femoral and tibial AC

Femoral and tibial AC focal CS significantly decreased in OA control rats compared with sham control rats. By contrast, the 200, 100 and $50 \mathrm{mg} / \mathrm{kg}$ combination treatment groups showed an increased femoral and tibial AC focal CS compared with the OA control group. In particular, the 200, 100 and 50 $\mathrm{mg} / \mathrm{kg}$ combination treatment groups showed dose-dependent and significant increases in focal CS for both femoral and tibial AC compared with the PCP, $\mathrm{EC}$ and AR single formula treatment groups (Fig 6).

Changes in $\mathrm{PGE}_{2}$ levels of the femoral and tibial AC with SM

$\mathrm{PGE}_{2}$ levels in the femoral and tibial AC with $\mathrm{SM}$ significantly increased in the OA control group compared with the sham control group. However, significant decreases in the femoral and tibial $\mathrm{AC}$ with $\mathrm{SM} \mathrm{PGE}_{2}$ levels were observed in all of test substance-treated groups compared with the OA control group. Particularly, the 200, 100 and $50 \mathrm{mg} / \mathrm{kg}$ combination-treated groups showed significant and

Table 2. Effects on $\mathrm{PGE}_{2}$ Levels of the Femur and Tibia $\mathrm{AC}$ with $\mathrm{SM}$

\begin{tabular}{|c|c|c|c|}
\hline & & PGE2 levels & \\
\hline Groups & Femur AC & Tibia AC & SM \\
\hline \multicolumn{4}{|l|}{ Controls } \\
\hline Sham & $42.62 \pm 10.55$ & $37.01 \pm 12.19$ & $32.24 \pm 12.83$ \\
\hline $\mathrm{OA}$ & $123.76 \pm 24.73^{\mathrm{a}}$ & $107.08 \pm 16.92^{\mathrm{a}}$ & $147.25 \pm 31.90^{\mathrm{a}}$ \\
\hline Diclofenac & $67.17 \pm 10.92^{\text {ac }}$ & $61.33 \pm 11.04^{\mathrm{ac}}$ & $82.29 \pm 14.01^{\mathrm{ac}}$ \\
\hline \multicolumn{4}{|c|}{ Single formula $(200 \mathrm{mg} / \mathrm{kg})$} \\
\hline $\mathrm{PCP}$ & $89.51 \pm 11.70^{\text {ac }}$ & $79.44 \pm 12.33^{\text {ac }}$ & $101.94 \pm 12.84^{\mathrm{ac}}$ \\
\hline $\mathrm{EC}$ & $93.98 \pm 10.51^{\mathrm{ac}}$ & $87.54 \pm 9.02^{\mathrm{ac}}$ & $110.92 \pm 11.50^{\text {ac }}$ \\
\hline AR & $93.59 \pm 15.54^{\mathrm{ac}}$ & $84.60 \pm 11.38^{\text {ac }}$ & $109.41 \pm 17.30^{\mathrm{ac}}$ \\
\hline \multicolumn{4}{|c|}{ Mixed formula - PCP:EC:AR 5:4:1 (g/g) } \\
\hline $200 \mathrm{mg} / \mathrm{kg}$ & $56.15 \pm 13.54^{\text {bcdef }}$ & $48.79 \pm 8.35^{\text {bcdef }}$ & $69.45 \pm 16.81$ acdef \\
\hline $100 \mathrm{mg} / \mathrm{kg}$ & $61.69 \pm 15.50^{\text {acdef }}$ & $56.33 \pm 16.82^{\text {acdef }}$ & $74.60 \pm 12.54^{\text {acdef }}$ \\
\hline $50 \mathrm{mg} / \mathrm{kg}$ & $67.93 \pm 12.07^{\text {acdef }}$ & $62.96 \pm 11.29$ acdef & $83.93 \pm 10.99^{\text {acdef }}$ \\
\hline
\end{tabular}

Data are shown as mean \pm SD of 10 rats, $\mathrm{g} / \mathrm{cm}^{2}$. OA, Osteoarthritis; AC, Articular cartilage; SM, Synovial membrane; PGE $_{2}$, Prostaglandin $\mathrm{E}_{2}$; PCP, Pomegranate Concentration Powder; EC, Aqueous extracts of Eucommiae Cortex; AR, Aqueous extracts of Achyranthis Radix. ${ }^{\mathrm{a}} \mathrm{p}<0.01$ and ${ }^{\mathrm{b}} \mathrm{p}<0.05$, compared to the sham control; ${ }^{\mathrm{c}} \mathrm{p}<0.01$, compared to the OA control; and ${ }^{\mathrm{d}} \mathrm{p}<0.01$, compared to the PCP only; ${ }^{\mathrm{e}}$ $\mathrm{p}<0.01$, compared to the EC only; $\mathrm{f}<<0.01$, compared to the AR only. 
dose-dependent decreases in $\mathrm{PGE}_{2}$ levels in the femoral and tibial AC with SM compared with the PCP, EC and AR single treatment groups (Table 2).

\section{5-LPO activity of the femoral and tibial AC with SM}

The 5-LPO activity of the femoral and tibial AC with SM significantly increased in the OA control group compared with the sham control group. However, significant decreases in the 5-LPO activity of the femoral and tibial AC with SM were observed in all test substance-treated groups compared with the OA control group. In particular, the 200, 100 and $50 \mathrm{mg} / \mathrm{kg}$ combination-treated groups showed dose-dependent and significant decreases in 5-LPO activity in the femoral and tibial AC with SM compared with the PCP, EC and AR single treatment groups (Table 3).

\section{Changes in the MMP-2 and MMP-9} activity of the femoral and tibial AC with SM

The MMP-2 and MMP-9 activity increased significantly in the OA control group compared with the sham control group. However, significant decreases in the femoral and tibial AC with SM MMP-2 and MMP-9 activity were observed in all of the test substance-treated groups compared with the OA control group. In particular, the 200, 100 and $50 \mathrm{mg} / \mathrm{kg}$ combined treatment groups showed dose-dependent decreases in MMP-2 and MMP-9 activity compared with the PCP, EC and AR single treatment groups (Table 4 and 5).

\section{Effects on the mRNA expression of collagen type II, SOX9 and aggrecan}

There was a significant reduction in the transcript levels of collagen type II, SOX9 and aggrecan in the femoral and tibial $\mathrm{AC}$, which were significantly higher in the OA control group compared with the sham control group (Table 6-8). However, dose-dependent increases in femoral and tibial AC, and decreases in the SM collagen type II mRNA expression were observed in the 200,100 and $50 \mathrm{mg} / \mathrm{kg}$

Table 3. Effects on 5-LPO Activities of Femur and Tibia AC with SM

\begin{tabular}{|c|c|c|c|}
\hline \multirow{2}{*}{ Groups } & \multicolumn{3}{|c|}{ 5-LPO activity } \\
\hline & Femur AC & Tibia AC & SM \\
\hline \multicolumn{4}{|l|}{ Controls } \\
\hline Sham & $0.18 \pm 0.08$ & $0.16 \pm 0.09$ & $0.23 \pm 0.09$ \\
\hline $\mathrm{OA}$ & $5.78 \pm 2.23^{\mathrm{a}}$ & $4.64 \pm 1.55^{\mathrm{a}}$ & $12.22 \pm 4.45^{\mathrm{a}}$ \\
\hline Diclofenac & $0.94 \pm 0.28^{\mathrm{ab}}$ & $0.88 \pm 0.24^{\mathrm{ab}}$ & $3.16 \pm 0.98^{a b}$ \\
\hline \multicolumn{4}{|c|}{ Single formula (200 mg/kg) } \\
\hline PCP & $1.70 \pm 0.45^{\mathrm{ab}}$ & $1.69 \pm 0.26^{\mathrm{ab}}$ & $5.50 \pm 1.12^{\mathrm{ab}}$ \\
\hline $\mathrm{EC}$ & $2.05 \pm 0.53^{\mathrm{ab}}$ & $1.94 \pm 0.30^{\mathrm{ab}}$ & $7.71 \pm 1.74^{\mathrm{ac}}$ \\
\hline $\mathrm{AR}$ & $2.01 \pm 0.54^{\mathrm{ab}}$ & $1.84 \pm 0.34^{\mathrm{ab}}$ & $6.60 \pm 1.35^{\mathrm{ab}}$ \\
\hline \multicolumn{4}{|c|}{ Mixed formula - PCP:EC:AR 5:4:1 (g/g) } \\
\hline $200 \mathrm{mg} / \mathrm{kg}$ & $0.62 \pm 0.16^{\text {abdef }}$ & $0.52 \pm 0.19$ abdef & $1.82 \pm 0.68^{\text {abdef }}$ \\
\hline $100 \mathrm{mg} / \mathrm{kg}$ & $0.72 \pm 0.22$ abdef & $0.69 \pm 0.19$ abdef & $2.36 \pm 0.51^{\text {abdef }}$ \\
\hline $50 \mathrm{mg} / \mathrm{kg}$ & $0.96 \pm 0.23$ abdef & $0.86 \pm 0.36^{\text {abdef }}$ & $3.14 \pm 1.11^{\text {abdef }}$ \\
\hline
\end{tabular}

Data are shown as mean \pm SD of 10 rats, $\mathrm{g} / \mathrm{cm}^{2}$. OA, Osteoarthritis; AC, Articular cartilage; SM, Synovial membrane; LPO, Lipoxygenase; PCP, Pomegranate Concentration Powder; EC, Aqueous extracts of Eucommiae Cortex; AR, Aqueous extracts of Achyranthis Radix. ${ }^{\text {a }}$ $\mathrm{p}<0.01$, compared to the sham control; ${ }^{\mathrm{b}} \mathrm{p}<0.01$ and ${ }^{\mathrm{c}} \mathrm{p}<0.05$, compared to the OA control; ${ }^{\mathrm{d}} \mathrm{p}<0.01$, compared to the PCP only; ${ }^{\mathrm{e}} \mathrm{p}<0.01$, compared to the EC only; ${ }^{\mathrm{f}} \mathrm{p}<0.01$, compared to the AR only. 
Anti-osteoarthritic effects of a combination of pomegranate concentrate powder, Eucommiae cortex and Achyranthis radix in rats

Table 4. Effects on MMP-2 Levels of Femur and Tibia AC with SM

\begin{tabular}{|c|c|c|c|}
\hline \multirow{2}{*}{ Groups } & \multicolumn{3}{|c|}{ MMP-2 activity } \\
\hline & Femur AC & Tibia AC & SM \\
\hline \multicolumn{4}{|l|}{ Controls } \\
\hline Sham & $1.03 \pm 0.21$ & $0.92 \pm 0.24$ & $0.89 \pm 0.28$ \\
\hline OA & $6.38 \pm 1.23 \mathrm{a}$ & $5.37 \pm 1.19 \mathrm{a}$ & $5.27 \pm 0.83 \mathrm{a}$ \\
\hline Diclofenac & $2.74 \pm 0.87 \mathrm{ab}$ & $2.85 \pm 0.59 \mathrm{ab}$ & $2.57 \pm 0.38 \mathrm{ab}$ \\
\hline \multicolumn{4}{|c|}{ Single formula $(200 \mathrm{mg} / \mathrm{kg})$} \\
\hline PCP & $3.76 \pm 0.86 \mathrm{ab}$ & $3.55 \pm 0.48 \mathrm{ab}$ & $3.38 \pm 0.57 \mathrm{ab}$ \\
\hline $\mathrm{EC}$ & $4.06 \pm 0.95 \mathrm{ab}$ & $3.92 \pm 0.71 \mathrm{ab}$ & $3.71 \pm 0.81 \mathrm{ab}$ \\
\hline $\mathrm{AR}$ & $4.94 \pm 0.66 \mathrm{ab}$ & $4.09 \pm 0.83 \mathrm{ac}$ & $4.00 \pm 0.92 \mathrm{ab}$ \\
\hline \multicolumn{4}{|c|}{ Mixed formula - PCP:EC:AR 5:4:1 (g/g) } \\
\hline $200 \mathrm{mg} / \mathrm{kg}$ & $2.05 \pm 0.30$ abdfg & $2.10 \pm 0.51 \mathrm{abdfg}$ & $2.10 \pm 0.55 \mathrm{abdfg}$ \\
\hline $100 \mathrm{mg} / \mathrm{kg}$ & $2.34 \pm 0.41 \mathrm{abdfg}$ & $2.32 \pm 0.56 \mathrm{abdfg}$ & $2.50 \pm 0.46 \mathrm{abdfg}$ \\
\hline $50 \mathrm{mg} / \mathrm{kg}$ & $2.73 \pm 0.59 \mathrm{abdfg}$ & $2.80 \pm 0.58 \mathrm{abdfg}$ & $2.75 \pm 0.39 \mathrm{abdfg}$ \\
\hline
\end{tabular}

Data are shown as mean \pm SD of 10 rats, $\mathrm{g} / \mathrm{cm}^{2}$. OA, Osteoarthritis; AC, Articular cartilage; SM, Synovial membrane; MMP, Matrix metalloproteinase. PCP, Pomegranate Concentration Powder; EC, Aqueous extracts of Eucommiae Cortex; AR, Aqueous extracts of Achyranthis Radix. ${ }^{\mathrm{a}} \mathrm{p}<0.01$, compared to the sham control; ${ }^{\mathrm{b}} \mathrm{p}<0.01$ and ${ }^{\mathrm{c}} \mathrm{p}<0.05$, compared to the OA control; ${ }^{\mathrm{d}} \mathrm{p}<0.01$ and ${ }^{\mathrm{e}} \mathrm{p}<0.05$, compared to the PCP only; ${ }^{\mathrm{f}} \mathrm{p}<0.01$, compared to the EC only; ${ }^{\mathrm{g}} \mathrm{p}<0.01$, compared to the AR only.

Table 5. Effects on MMP-9 Levels of Femur and Tibia AC with SM

\begin{tabular}{|c|c|c|c|}
\hline \multirow{2}{*}{ Groups } & \multicolumn{3}{|c|}{ MMP-9 activity } \\
\hline & Femur AC & Tibia AC & SM \\
\hline \multicolumn{4}{|l|}{ Controls } \\
\hline Sham & $1.08 \pm 0.49$ & $0.96 \pm 0.51$ & $0.83 \pm 0.19$ \\
\hline $\mathrm{OA}$ & $5.26 \pm 1.58^{\mathrm{a}}$ & $4.83 \pm 0.72^{\mathrm{a}}$ & $4.97 \pm 0.83^{\mathrm{a}}$ \\
\hline Diclofenac & $2.42 \pm 0.48^{\mathrm{ab}}$ & $2.31 \pm 0.38^{\mathrm{ab}}$ & $2.25 \pm 0.40^{\mathrm{ab}}$ \\
\hline \multicolumn{4}{|c|}{ Single formula $(200 \mathrm{mg} / \mathrm{kg})$} \\
\hline PCP & $3.17 \pm 0.58^{\mathrm{ab}}$ & $3.02 \pm 0.39^{\mathrm{ab}}$ & $3.18 \pm 0.59^{\mathrm{ab}}$ \\
\hline $\mathrm{EC}$ & $3.47 \pm 0.62^{\mathrm{ab}}$ & $3.53 \pm 0.51^{\mathrm{ab}}$ & $3.69 \pm 0.76^{\mathrm{ab}}$ \\
\hline AR & $3.55 \pm 0.62^{\mathrm{ab}}$ & $3.55 \pm 0.99^{\mathrm{ab}}$ & $3.76 \pm 0.82^{\mathrm{ab}}$ \\
\hline \multicolumn{4}{|c|}{ Mixed formula - PCP:EC:AR 5:4:1 (g/g) } \\
\hline $200 \mathrm{mg} / \mathrm{kg}$ & $2.06 \pm 0.39^{\text {abcde }}$ & $1.75 \pm 0.39$ abcde & $1.86 \pm 0.63$ abcde \\
\hline $100 \mathrm{mg} / \mathrm{kg}$ & $2.23 \pm 0.40$ abcde & $2.05 \pm 0.68$ abcde & $2.13 \pm 0.65$ abcde \\
\hline $50 \mathrm{mg} / \mathrm{kg}$ & $2.43 \pm 0.41$ abcde & $2.34 \pm 0.41^{\text {abcde }}$ & $2.30 \pm 0.58^{\text {abcde }}$ \\
\hline
\end{tabular}

Data are shown as mean \pm SD of 10 rats, $\mathrm{g} / \mathrm{cm}^{2}$. OA, Osteoarthritis; PCP, Pomegranate Concentration Powder; AR, Aqueous extracts of Achyranthis Radix; EC, Aqueous extracts of Eucommiae Cortex; AC, Articular cartilage; SM, Synovial membrane; MMP, Matrix metalloproteinase. ${ }^{\mathrm{a}} \mathrm{p}<0.01$, compared to the sham control; ${ }^{\mathrm{b}} \mathrm{p}<0.01$, compared to the OA control; ${ }^{\mathrm{c}} \mathrm{p}<0.01$ and ${ }^{\mathrm{d}} \mathrm{p}<0.05$, compared to the PCP only; ${ }^{\mathrm{e}} \mathrm{p}<0.01$, compared to the EC only; ${ }^{\mathrm{f}} \mathrm{p}<0.01$, compared to the AR only.

combination-treated groups compared with the OA control group (Table 6). SOX9 mRNA expression in the femoral and tibial AC with SM dose-dependently increased in the 200, 100 and $50 \mathrm{mg} / \mathrm{kg}$ combination-treated groups compared with the OA control group (Table 7). Aggrecan mRNA expression in the femoral and tibial AC with SM also dose-dependently increased in the 200, 100 and 50 
Journal of Korean Medicine 2018;39(4)

Table 6. Femur and Tibia AC with SM Collagen Type II mRNA Levels

\begin{tabular}{|c|c|c|c|}
\hline \multirow{2}{*}{ Groups } & \multicolumn{3}{|c|}{ Collagen type II mRNA expressions } \\
\hline & Femur AC & Tibia AC & SM \\
\hline \multicolumn{4}{|l|}{ Controls } \\
\hline Sham & $1.02 \pm 0.15$ & $1.05 \pm 0.21$ & $0.91 \pm 0.17$ \\
\hline $\mathrm{OA}$ & $0.24 \pm 0.09^{\mathrm{a}}$ & $0.23 \pm 0.06^{\mathrm{a}}$ & $7.25 \pm 1.32^{\mathrm{a}}$ \\
\hline Diclofenac & $0.51 \pm 0.10^{\mathrm{ab}}$ & $0.44 \pm 0.06^{\mathrm{ab}}$ & $3.94 \pm 0.90^{\text {ab }}$ \\
\hline \multicolumn{4}{|c|}{ Single formula $(200 \mathrm{mg} / \mathrm{kg})$} \\
\hline $\mathrm{PCP}$ & $0.41 \pm 0.10^{\mathrm{ab}}$ & $0.37 \pm 0.05^{\mathrm{ab}}$ & $4.80 \pm 0.90^{\mathrm{ab}}$ \\
\hline $\mathrm{EC}$ & $0.38 \pm 0.08^{a b}$ & $0.32 \pm 0.07^{\mathrm{ab}}$ & $5.11 \pm 0.73^{\mathrm{ab}}$ \\
\hline $\mathrm{AR}$ & $0.36 \pm 0.09 \mathrm{ac}$ & $0.32 \pm 0.05^{\mathrm{ab}}$ & $5.28 \pm 0.75^{\mathrm{ab}}$ \\
\hline \multicolumn{4}{|c|}{ Mixed formula - PCP:EC:AR 5:4:1 (g/g) } \\
\hline $200 \mathrm{mg} / \mathrm{kg}$ & $0.63 \pm 0.13^{\text {abdfg }}$ & $0.56 \pm 0.09^{\text {abdfg }}$ & $2.88 \pm 0.58^{\mathrm{abdfg}}$ \\
\hline $100 \mathrm{mg} / \mathrm{kg}$ & $0.58 \pm 0.13^{\text {abdfg }}$ & $0.50 \pm 0.09^{\mathrm{abdfg}}$ & $3.23 \pm 0.61^{\mathrm{abdfg}}$ \\
\hline $50 \mathrm{mg} / \mathrm{kg}$ & $0.53 \pm 0.09^{\text {abefg }}$ & $0.45 \pm 0.06^{\text {abdfg }}$ & $3.72 \pm 0.55^{\mathrm{abdfg}}$ \\
\hline
\end{tabular}

Data are shown as mean $\pm \mathrm{SD}$ of 10 rats, $\mathrm{g} / \mathrm{cm}^{2}$. The mRNA level of $\beta$-actin was used as a control. OA, Osteoarthritis; PCP, Pomegranate Concentration Powder; AR, Aqueous extracts of Achyranthis Radix; EC, Aqueous extracts of Eucommiae Cortex; AC, Articular cartilage; $\mathrm{SM}$, Synovial membrane. ${ }^{\mathrm{a}} \mathrm{p}<0.01$, compared to the sham control; ${ }^{\mathrm{b}} \mathrm{p}<0.01$, compared to the OA control; ${ }^{\mathrm{c}} \mathrm{p}<0.05$, compared to the PCP only; ${ }^{\mathrm{d}} \mathrm{p}<0.01$, compared to the EC only; and ${ }^{\mathrm{e}} \mathrm{p}<0.01$, compared to the AR only.

Table 7. Femur and Tibia AC with SM SOX9 mRNA Levels

\begin{tabular}{|c|c|c|c|}
\hline \multirow[b]{2}{*}{ Groups } & \multicolumn{3}{|c|}{ SOX9 mRNA expressions } \\
\hline & Femur AC & Tibia AC & SM \\
\hline \multicolumn{4}{|l|}{ Controls } \\
\hline Sham & $0.99 \pm 0.13$ & $1.05 \pm 0.19$ & $0.92 \pm 0.16$ \\
\hline $\mathrm{OA}$ & $0.16 \pm 0.04^{\mathrm{a}}$ & $0.17 \pm 0.05^{\text {a }}$ & $0.12 \pm 0.04^{\mathrm{a}}$ \\
\hline Diclofenac & $0.43 \pm 0.07^{\mathrm{ab}}$ & $0.41 \pm 0.07^{\mathrm{ab}}$ & $0.33 \pm 0.08^{\mathrm{ab}}$ \\
\hline \multicolumn{4}{|c|}{ Single formula $(200 \mathrm{mg} / \mathrm{kg})$} \\
\hline $\mathrm{PCP}$ & $0.32 \pm 0.06^{\mathrm{ab}}$ & $0.31 \pm 0.06^{\mathrm{ab}}$ & $0.22 \pm 0.05^{\mathrm{ab}}$ \\
\hline EC & $0.26 \pm 0.05^{\mathrm{ab}}$ & $0.26 \pm 0.07^{\mathrm{ab}}$ & $0.20 \pm 0.05^{\mathrm{ab}}$ \\
\hline AR & $0.24 \pm 0.07^{\text {ac }}$ & $0.24 \pm 0.06^{\mathrm{ac}}$ & $0.19 \pm 0.03^{\mathrm{ab}}$ \\
\hline \multicolumn{4}{|c|}{ Mixed formula - PCP:EC:AR 5:4:1 (g/g) } \\
\hline $200 \mathrm{mg} / \mathrm{kg}$ & $0.54 \pm 0.07^{\text {abdef }}$ & $0.50 \pm 0.09$ abdef & $0.48 \pm 0.08$ abdef \\
\hline $100 \mathrm{mg} / \mathrm{kg}$ & $0.48 \pm 0.08^{\text {abdef }}$ & $0.45 \pm 0.08^{\text {abdef }}$ & $0.39 \pm 0.09$ abdef \\
\hline $50 \mathrm{mg} / \mathrm{kg}$ & $0.42 \pm 0.06^{\text {abdef }}$ & $0.41 \pm 0.09^{\text {abdef }}$ & $0.32 \pm 0.08^{\text {abdef }}$ \\
\hline
\end{tabular}

Data are shown as mean $\pm \mathrm{SD}$ of 10 rats, $\mathrm{g} / \mathrm{cm}^{2}$. The mRNA level of $\beta$-actin was used as a control. OA, Osteoarthritis; Articular cartilage; SM, Synovial membrane; SOX9, SRY (sex determining region Y)-box 9; PCP, Pomegranate Concentration Powder; AR, Aqueous extracts of Achyranthis Radix; EC, Aqueous extracts of Eucommiae Cortex; AC. ${ }^{a} \mathrm{p}<0.01$, compared to the sham control; ${ }^{b} \mathrm{p}<0.01$ and ${ }^{\mathrm{c}} \mathrm{p}<0.05$, compared to the OA control; ${ }^{\mathrm{d}} \mathrm{p}<0.01$, compared to the PCP only; ${ }^{\mathrm{e}} \mathrm{p}<0.01$, compared to the EC only; ${ }^{\mathrm{f}} \mathrm{p}<0.01$, compared to the AR only.

$\mathrm{mg} / \mathrm{kg}$ combination-treated groups compared with the OA control rats (Table 8).

\section{Effects on the number of BrdU-immunoreactive cells in femoral and tibial AC with SM}

The number of BrdU-immunoreactive cells in the 
Anti-osteoarthritic effects of a combination of pomegranate concentrate powder, Eucommiae cortex and Achyranthis radix in rats

Table 8. Femur and Tibia AC with SM Aggrecan mRNA Expressions Levels

\begin{tabular}{|c|c|c|c|}
\hline \multirow{2}{*}{ Groups } & \multicolumn{3}{|c|}{ Aggrecan mRNA expressions } \\
\hline & Femur AC & Tibia AC & SM \\
\hline \multicolumn{4}{|l|}{ Controls } \\
\hline Sham & $1.00 \pm 0.17$ & $1.10 \pm 0.19$ & $1.00 \pm 0.15$ \\
\hline $\mathrm{OA}$ & $0.11 \pm 0.05^{\mathrm{a}}$ & $0.10 \pm 0.05^{\mathrm{a}}$ & $0.11 \pm 0.06^{\mathrm{a}}$ \\
\hline Diclofenac & $0.36 \pm 0.14^{\mathrm{ab}}$ & $0.30 \pm 0.09^{\mathrm{ab}}$ & $0.33 \pm 0.10^{\mathrm{ab}}$ \\
\hline \multicolumn{4}{|c|}{ Single formula $(200 \mathrm{mg} / \mathrm{kg})$} \\
\hline PCP & $0.24 \pm 0.07^{\mathrm{ab}}$ & $0.23 \pm 0.05^{\mathrm{ab}}$ & $0.23 \pm 0.04^{\mathrm{ab}}$ \\
\hline $\mathrm{EC}$ & $0.20 \pm 0.02^{\mathrm{ab}}$ & $0.19 \pm 0.03^{\mathrm{ab}}$ & $0.19 \pm 0.02^{\mathrm{ab}}$ \\
\hline AR & $0.20 \pm 0.05^{\mathrm{ab}}$ & $0.18 \pm 0.05^{\mathrm{ab}}$ & $0.19 \pm 0.03^{\mathrm{ab}}$ \\
\hline \multicolumn{4}{|c|}{ Mixed formula - PCP:EC:AR 5:4:1 (g/g) } \\
\hline $200 \mathrm{mg} / \mathrm{kg}$ & $0.45 \pm 0.09^{\text {abcde }}$ & $0.42 \pm 0.08$ abcde & $0.48 \pm 0.10^{\text {abcde }}$ \\
\hline $100 \mathrm{mg} / \mathrm{kg}$ & $0.41 \pm 0.10$ abcde & $0.35 \pm 0.08$ abcde & $0.41 \pm 0.08$ abcde \\
\hline $50 \mathrm{mg} / \mathrm{kg}$ & $0.34 \pm 0.08^{\text {abcde }}$ & $0.31 \pm 0.05$ abcde & $0.35 \pm 0.08^{\text {abcde }}$ \\
\hline
\end{tabular}

Data are shown as mean $\pm \mathrm{SD}$ of 10 rats, $\mathrm{g} / \mathrm{cm}^{2}$. The mRNA level of $\beta$-actin was used as a control. OA, Osteoarthritis; Articular cartilage; SM, Synovial membrane; PCP, Pomegranate Concentration Powder; AR, Aqueous extracts of Achyranthis Radix; EC, Aqueous extracts of Eucommiae Cortex; AC. ${ }^{a} \mathrm{p}<0.01$, compared to the sham control; ${ }^{\mathrm{b}} \mathrm{p}<0.01$, compared to the OA control; and ${ }^{\mathrm{c}} \mathrm{p}<0.01$, compared to the PCP only; and ${ }^{\mathrm{d}} \mathrm{p}<0.01$, compared to the EC only; and ${ }^{\mathrm{e}} \mathrm{p}<0.01$, compared to the AR only.

Table 9. Femur and Tibia AC with SM BrdU-immunoreactive Cell Numbers in Sham-operated or OA Rats

\begin{tabular}{|c|c|c|c|}
\hline \multirow[b]{2}{*}{ Groups } & \multicolumn{3}{|c|}{ BrdU-immunoreactive cell numbers } \\
\hline & Femur AC & Tibia AC & SM \\
\hline \multicolumn{4}{|l|}{ Controls } \\
\hline Sham & $120.60 \pm 30.86$ & $85.00 \pm 14.09$ & $87.40 \pm 24.54$ \\
\hline $\mathrm{OA}$ & $46.10 \pm 10.52^{\mathrm{a}}$ & $33.30 \pm 12.70^{\mathrm{a}}$ & $789.70 \pm 104.62^{\mathrm{a}}$ \\
\hline Diclofenac & $44.90 \pm 13.41^{\mathrm{a}}$ & $32.90 \pm 11.74^{\mathrm{a}}$ & $238.80 \pm 67.06^{\mathrm{ac}}$ \\
\hline \multicolumn{4}{|c|}{ Single formula $(200 \mathrm{mg} / \mathrm{kg})$} \\
\hline PCP & $111.70 \pm 22.44^{\mathrm{ac}}$ & $126.60 \pm 27.32^{\text {ac }}$ & $419.40 \pm 89.10^{\text {ac }}$ \\
\hline $\mathrm{EC}$ & $76.90 \pm 19.07^{\mathrm{ac}}$ & $94.40 \pm 19.83^{\mathrm{c}}$ & $538.90 \pm 102.56^{\mathrm{ac}}$ \\
\hline $\mathrm{AR}$ & $92.40 \pm 12.61^{\mathrm{bc}}$ & $75.20 \pm 16.22^{\mathrm{c}}$ & $626.40 \pm 122.35^{\text {ac }}$ \\
\hline \multicolumn{4}{|c|}{ Mixed formula - PCP:EC:AR 5:4:1 (g/g) } \\
\hline $200 \mathrm{mg} / \mathrm{kg}$ & $323.10 \pm 123.08^{\text {acdef }}$ & $315.30 \pm 109.46^{\text {acdef }}$ & $126.80 \pm 37.60^{\text {acdef }}$ \\
\hline $100 \mathrm{mg} / \mathrm{kg}$ & $235.60 \pm 74.56^{\mathrm{acdef}}$ & $227.00 \pm 60.81^{\text {acdef }}$ & $182.30 \pm 41.83^{\text {acdef }}$ \\
\hline $50 \mathrm{mg} / \mathrm{kg}$ & $178.30 \pm 28.55^{\text {acdef }}$ & $183.10 \pm 27.57^{\text {acdef }}$ & $265.20 \pm 82.74^{\text {acdef }}$ \\
\hline
\end{tabular}

Values are expressed mean $\pm \mathrm{SD}$ of 10 rats, cells $/ \mathrm{mm}^{2} . \mathrm{AR}=$ Aqueous extracts of Achyranthis Radix; $\mathrm{OA}=$ Osteoarthritis; $\mathrm{EC}=\mathrm{Aqueous}$ extracts of Eucommiae Cortex; $\mathrm{PCP}=$ Pomegranate Concentration Powder; AC = Articular cartilage; $\mathrm{SM}=$ Synovial membrane; $\mathrm{BrdU}=$ 5-Bromo-2'-Deoxyuridine. ${ }^{a} \mathrm{p}<0.01$ and ${ }^{\mathrm{b}} \mathrm{p}<0.05$ as compared with sham control; ${ }^{\mathrm{c}} \mathrm{p}<0.01$ as compared with OA control; ${ }^{\mathrm{d}} \mathrm{p}<0.01$ as compared with PCP single formula; ${ }^{\mathrm{e}} \mathrm{p}<0.01$ as compared with EC single formula; ${ }^{\mathrm{f}} \mathrm{p}<0.01$ as compared with AR single formula.

femoral and tibial $\mathrm{AC}$ was significantly reduced in the OA control group, and increased in the OA control group compared with the sham control group. Significant increases in the number of femoral and tibial
AC BrdU-immunoreactive cells, and decreases in the number of SM BrdU-immunoreactive cells were observed in all of the test substance-treatment groups compared with the OA control group, with exception 


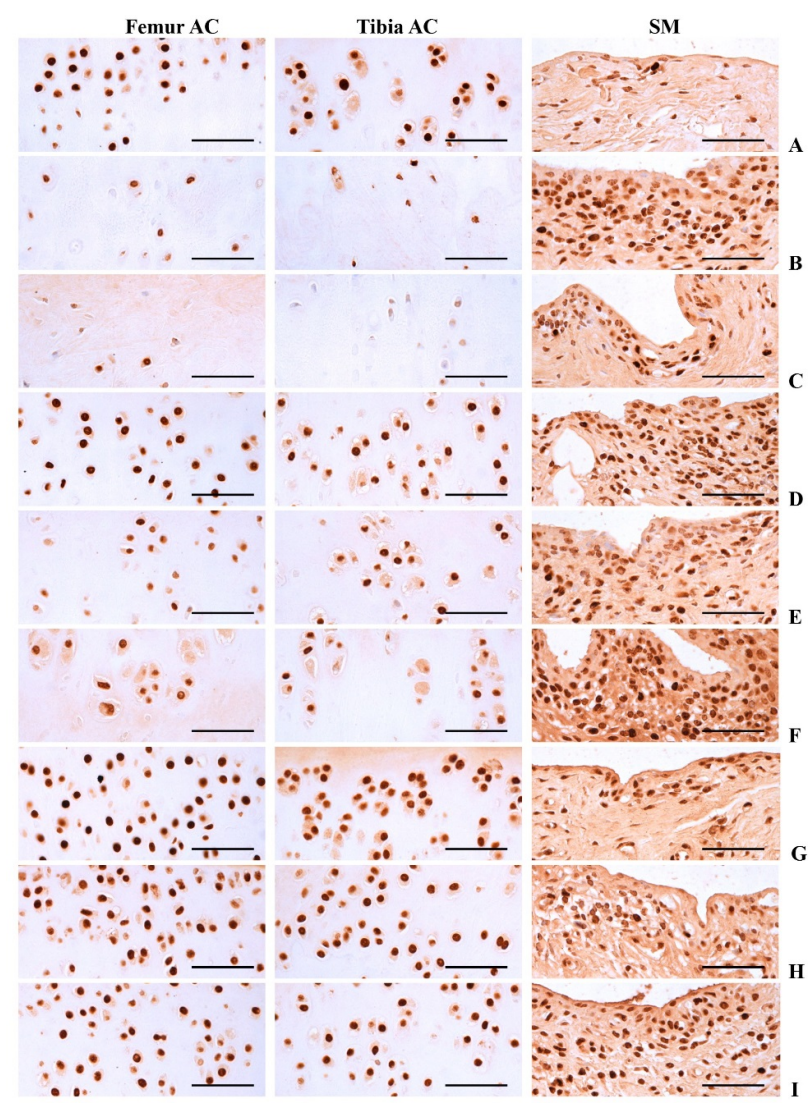

Fig. 7. Effect of mixed formulation (Pomegranate Concentration Powder (PCP): Aqueous extracts of Eucommiae Cortex (EC): Aqueous extracts Achyranthis Radix (AR) 5:4:1 (g/g) on the BrdU (5-Bromo-2'-Deoxyuridine)-immunoreactive cells on the femur and tibia AC (Articular cartilage) with Synovial membrane (SM) in surgically induced osteoarthritis (OA). Immunohistochemistrical images shown are representative of ten rats per each groups. (A), Sham vehicle control; (B), OA control; (C), OA-surgery+ diclofenac sodium 2 $\mathrm{mg} / \mathrm{kg}$ subcutaneously; (D), OA-surgery+ 200 $\mathrm{mg} / \mathrm{kg}$ PCP only; (E), OA-surgery+200 mg/kg EC only; (F), OA-surgery+200 mg/kg AR only; (G), 200 $\mathrm{mg} / \mathrm{kg}$ PCP:EC:AR 5:4:1 (g/g); (H), $100 \mathrm{mg} / \mathrm{kg}$ PCP:EC:AR 5:4:1 (g/g) mixed formula; (I), $50 \mathrm{mg} / \mathrm{kg}$ PCP:EC:AR 5:4:1 (g/g) mixed formula. $A B C=$ Avidin-biotin complex. All ABC immunostain. Scale bars $=120 \mu \mathrm{m}$.

of the diclofenac-treated group, in which a similar number of BrdU-immunoreactive cells was detected in the femoral and tibial $\mathrm{AC}$ compared with the $\mathrm{OA}$ control group. In particular, the 200,100 and $50 \mathrm{mg} / \mathrm{kg}$ combination treatment groups showed significant dose-dependent increases in the number of BrdU-immunolabeled cells in the femoral and tibial $\mathrm{AC}$, but decreases in the SM compared with the PCP, $\mathrm{EC}$ and AR single treatment groups (Fig 7, Table 9).

\section{Changes in the femoral and tibial $\mathrm{AC}$ Mankin scores}

In the OA control rats, the surface of the cartilage became rough and the number of chondrocytes decreased. Safranin-O stain intensities were reduced on the femoral and tibial AC, and femoral and tibial AC Mankin scores in the OA control group were significantly higher than those of the sham control group. However, significant decreases in the femoral and tibial AC Mankin scores were observed in all of the test substance-treated groups compared to the OA control group. In particular, the 200,100 and $50 \mathrm{mg} / \mathrm{kg}$ combination treatment groups showed dose-dependent decreases in the femoral and tibial AC Mankin scores compared with the PCP, EC and AR single treatment groups (Table 10 and 11). 
Anti-osteoarthritic effects of a combination of pomegranate concentrate powder, Eucommiae cortex and Achyranthis radix in rats

Table 10. Effects of PCP:EC:AR 5:4:1 (g/g) Mixed Formula on Femur AC Mankin Scores

\begin{tabular}{|c|c|c|c|c|c|}
\hline \multirow{2}{*}{ Groups } & Items & \multicolumn{3}{|c|}{ Mankin scores } & \multirow[b]{2}{*}{ Total* } \\
\hline & Surface & Cellularity & Clone & Stain intensity & \\
\hline \multicolumn{6}{|l|}{ Controls } \\
\hline Sham & $0.60 \pm 0.70$ & $0.70 \pm 0.48$ & $0.50 \pm 0.53$ & $1.10 \pm 0.57$ & $2.90 \pm 1.60$ \\
\hline $\mathrm{OA}$ & $2.80 \pm 0.42^{\mathrm{a}}$ & $2.70 \pm 0.48^{\mathrm{a}}$ & $2.80 \pm 0.42^{\mathrm{a}}$ & $2.60 \pm 0.97^{\mathrm{a}}$ & $10.90 \pm 1.20^{\mathrm{a}}$ \\
\hline Diclofenac & $1.80 \pm 0.79^{\text {ac }}$ & $1.30 \pm 0.48^{\mathrm{c}}$ & $1.60 \pm 0.84^{\mathrm{ac}}$ & $1.40 \pm 0.52^{\mathrm{c}}$ & $6.10 \pm 1.85^{\text {ac }}$ \\
\hline \multicolumn{6}{|c|}{ Single formula (200 mg/kg) } \\
\hline PCP & $2.30 \pm 0.48^{\text {a }}$ & $1.80 \pm 0.42^{\text {ac }}$ & $1.80 \pm 0.63^{\mathrm{ac}}$ & $1.60 \pm 0.70 \mathrm{c}$ & $7.50 \pm 1.43^{\text {ac }}$ \\
\hline $\mathrm{EC}$ & $2.50 \pm 0.53^{\mathrm{a}}$ & $2.00 \pm 0.47^{\text {ad }}$ & $1.90 \pm 0.57^{\mathrm{ac}}$ & $2.10 \pm 0.57^{\mathrm{a}}$ & $8.50 \pm 1.08^{a c}$ \\
\hline $\mathrm{AR}$ & $2.40 \pm 0.70^{\mathrm{a}}$ & $2.20 \pm 0.42^{\mathrm{a}}$ & $2.10 \pm 0.74^{\mathrm{ad}}$ & $2.00 \pm 0.82^{\mathrm{ad}}$ & $8.70 \pm 0.70$ ac \\
\hline \multicolumn{6}{|c|}{ Mixed formula - PCP:EC:AR 5:4:1 (g/g) } \\
\hline $200 \mathrm{mg} / \mathrm{kg}$ & $1.10 \pm 0.57^{\text {cegi }}$ & $1.00 \pm 0.00^{\text {cegi }}$ & $1.10 \pm 0.57^{\text {bcfgi }}$ & $1.10 \pm 0.57^{\mathrm{cgi}}$ & $4.30 \pm 0.67^{\text {bcegi }}$ \\
\hline $100 \mathrm{mg} / \mathrm{kg}$ & $1.20 \pm 0.42^{\text {bcegi }}$ & $1.00 \pm 0.47^{\text {cegi }}$ & $1.20 \pm 0.42^{\text {bcfhi }}$ & $1.30 \pm 0.67^{\mathrm{cgj}}$ & $4.70 \pm 0.82^{\text {acegi }}$ \\
\hline $50 \mathrm{mg} / \mathrm{kg}$ & $1.70 \pm 0.67^{\mathrm{acfgj}}$ & $1.40 \pm 0.52^{\text {bchi }}$ & $1.40 \pm 0.52^{\text {acj }}$ & $1.40 \pm 0.52^{\text {chj }}$ & $5.90 \pm 0.74^{\text {acegi }}$ \\
\hline
\end{tabular}

Data are shown as mean $\pm \mathrm{SD}$ of 10 rats, $\mathrm{g} / \mathrm{cm}^{2}$. Possible scores ranged from 0 to 12 . OA, Osteoarthritis; AC, Articular cartilage; SM, Synovial membrane; PCP, Pomegranate Concentration Powder; AR, Aqueous extracts of Achyranthis Radix; EC, Aqueous extracts of Eucommiae Cortex; AC. ${ }^{a} \mathrm{p}<0.01$ and ${ }^{\mathrm{b}} \mathrm{p}<0.05$, compared to the sham control; ${ }^{\mathrm{c}} \mathrm{p}<0.01$ and ${ }^{\mathrm{d}} \mathrm{p}<0.05$, compared to the OA control; and ${ }^{\mathrm{e}} \mathrm{p}<0.01$ and ${ }^{\mathrm{f}}$ $\mathrm{p}<0.05$, compared to the PCP only; ${ }^{\mathrm{g}} \mathrm{p}<0.01$ and ${ }^{\mathrm{h}} \mathrm{p}<0.05$, compared to the EC only; ${ }^{\mathrm{i}} \mathrm{p}<0.01$ and ${ }^{\mathrm{j}} \mathrm{p}<0.05$, compared to the AR only.

Table 11. Effects of PCP:EC:AR 5:4:1 (g/g) mixed Formula on Tibia AC Mankin Scores

\begin{tabular}{|c|c|c|c|c|c|}
\hline \multirow{2}{*}{ Groups } & \multicolumn{5}{|c|}{ Mankin scores } \\
\hline & Surface & Cellularity & Clone & Stain intensity & Total* \\
\hline \multicolumn{6}{|l|}{ Controls } \\
\hline Sham & $0.70 \pm 0.6770$ & $0.70 \pm 0.67$ & $0.60 \pm 0.52$ & $0.80 \pm 0.63$ & $2.80 \pm 1.32$ \\
\hline $\mathrm{OA}$ & $2.70 \pm 0.48^{\mathrm{a}}$ & $2.70 \pm 0.48^{\mathrm{a}}$ & $2.80 \pm 0.42^{\mathrm{a}}$ & $2.50 \pm 0.53^{\mathrm{a}}$ & $10.70 \pm 1.06^{\mathrm{a}}$ \\
\hline Diclofenac & $1.60 \pm 0.70$ ac & $1.60 \pm 0.52^{\mathrm{ac}}$ & $1.20 \pm 0.42^{\mathrm{bc}}$ & $1.50 \pm 0.53^{\mathrm{ac}}$ & $5.90 \pm 1.60^{\text {ac }}$ \\
\hline \multicolumn{6}{|c|}{ Single formula $(200 \mathrm{mg} / \mathrm{kg})$} \\
\hline PCP & $2.10 \pm 0.57^{\text {ad }}$ & $1.90 \pm 0.32$ ac & $1.80 \pm 0.63^{\mathrm{ac}}$ & $1.60 \pm 0.70$ ac & $7.40 \pm 0.97^{\text {ac }}$ \\
\hline $\mathrm{EC}$ & $2.50 \pm 0.71^{\mathrm{a}}$ & $1.90 \pm 0.74^{\mathrm{ac}}$ & $1.90 \pm 0.74^{\mathrm{ac}}$ & $2.00 \pm 0.47^{\mathrm{ad}}$ & $8.30 \pm 1.89^{\text {ac }}$ \\
\hline $\mathrm{AR}$ & $2.40 \pm 0.70^{\mathrm{a}}$ & $2.20 \pm 0.63^{\mathrm{ad}}$ & $2.20 \pm 0.42^{\mathrm{ad}}$ & $1.80 \pm 0.63^{\mathrm{ac}}$ & $8.60 \pm 1.43^{\text {ac }}$ \\
\hline \multicolumn{6}{|c|}{ Mixed formula - PCP:EC:AR 5:4:1 (g/g) } \\
\hline $200 \mathrm{mg} / \mathrm{kg}$ & $1.20 \pm 0.42^{\text {cegi }}$ & $0.80 \pm 0.42^{\mathrm{cegi}}$ & $1.20 \pm 0.63^{\text {bcfgi }}$ & $1.10 \pm 0.57^{\mathrm{cfgi}}$ & $4.30 \pm 1.25^{\text {bcegi }}$ \\
\hline $100 \mathrm{mg} / \mathrm{kg}$ & $1.20 \pm 0.42^{\text {cegi }}$ & $1.00 \pm 0.47^{\mathrm{cegi}}$ & $1.10 \pm 0.57^{\text {bcegi }}$ & $1.80 \pm 0.42^{\mathrm{ac}}$ & $5.10 \pm 0.99^{\text {acegi }}$ \\
\hline $50 \mathrm{mg} / \mathrm{kg}$ & $1.90 \pm 0.57^{\text {ach }}$ & $1.20 \pm 0.42^{\text {bcegi }}$ & $1.30 \pm 0.48^{\text {acfhi }}$ & $1.40 \pm 0.52^{\text {bch }}$ & $5.80 \pm 1.40^{\text {acfgi }}$ \\
\hline
\end{tabular}

Data are shown as mean $\pm \mathrm{SD}$ of 10 rats, $\mathrm{g} / \mathrm{cm}^{2}$. Possible scores ranged from 0 to 12. OA, Osteoarthritis; AC, Articular cartilage; SM, Synovial membrane; PCP, Pomegranate Concentration Powder; AR, Aqueous extracts of Achyranthis Radix; EC, Aqueous extracts of Eucommiae Cortex; AC. ${ }^{\mathrm{a}} \mathrm{p}<0.01$ and ${ }^{\mathrm{b}} \mathrm{p}<0.05$, compared to the sham control; ${ }^{\mathrm{c}} \mathrm{p}<0.01$ and ${ }^{\mathrm{d}} \mathrm{p}<0.05$, compared to the OA control; and ${ }^{\mathrm{e}}$ $\mathrm{p}<0.01$ and ${ }^{\mathrm{f}} \mathrm{p}<0.05$, compared to the PCP only; ${ }^{\mathrm{g}} \mathrm{p}<0.01$ and ${ }^{\mathrm{h}} \mathrm{p}<0.05$, compared to the EC only; ${ }^{\mathrm{i}} \mathrm{p}<0.01$, compared to the AR only.

Changes in the general histopathology of the femoral and tibial AC with SM

Remarkable reductions in the femoral and tibial AC thickness were observed in the OA control group compared with the sham control group, and significant increases in the SM epithelial lining thickness were detected in the OA control group. In contrast, remarkable increases in the thicknesses of the femoral and tibial $\mathrm{AC}$, and significant decreases in the SM epithelial lining thickness were detected in all test substance-treated groups compared with the OA control group. Of note, the 200,100 , and $50 \mathrm{mg} / \mathrm{kg}$ combination treatment 
Table 12. Femur and Tibia AC with SM General Histomorphometrical Analysis in Sham-Operated or OA Rats

\begin{tabular}{|c|c|c|c|c|}
\hline \multirow[b]{2}{*}{ Groups } & \multicolumn{4}{|c|}{ General histomorphometry } \\
\hline & $\begin{array}{l}\text { Femur AC thickness } \\
\qquad(\mu \mathrm{m})\end{array}$ & $\begin{array}{l}\text { Tibia AC thickness } \\
(\mu \mathrm{m})\end{array}$ & $\begin{array}{l}\text { SM epithelial thickness } \\
(\mu \mathrm{m})\end{array}$ & $\begin{array}{l}\text { SM IF cells } \\
\left(\times 10 \text { cells } / \mathrm{mm}^{2}\right)\end{array}$ \\
\hline \multicolumn{5}{|l|}{ Controls } \\
\hline Sham & $381.95 \pm 46.21$ & $380.56 \pm 44.74$ & $12.12 \pm 3.64$ & $31.60 \pm 12.13$ \\
\hline $\mathrm{OA}$ & $170.14 \pm 31.71^{\mathrm{a}}$ & $83.87 \pm 17.60^{\mathrm{a}}$ & $39.88 \pm 6.18^{\mathrm{a}}$ & $468.70 \pm 82.19^{\mathrm{a}}$ \\
\hline Diclofenac & $298.23 \pm 34.20^{\text {ac }}$ & $284.88 \pm 28.65^{\text {ac }}$ & $28.10 \pm 4.87^{\text {ac }}$ & $114.00 \pm 26.88^{\mathrm{ac}}$ \\
\hline \multicolumn{5}{|c|}{ Single formula $(200 \mathrm{mg} / \mathrm{kg})$} \\
\hline PCP & $269.04 \pm 23.70^{\text {ac }}$ & $252.87 \pm 19.35^{\text {ac }}$ & $26.84 \pm 2.68^{\text {ac }}$ & $256.10 \pm 46.40^{\mathrm{ac}}$ \\
\hline EC & $227.14 \pm 20.76^{\mathrm{ac}}$ & $215.13 \pm 30.15^{\text {ac }}$ & $30.63 \pm 3.02^{\mathrm{ac}}$ & $379.60 \pm 59.09^{\mathrm{ad}}$ \\
\hline AR & $219.44 \pm 26.64^{\mathrm{ac}}$ & $214.43 \pm 21.77^{\mathrm{ac}}$ & $28.14 \pm 2.57^{\mathrm{ac}}$ & $358.40 \pm 53.08^{\mathrm{ac}}$ \\
\hline \multicolumn{5}{|c|}{ Mixed formula - PCP:EC:AR 5:4:1 (g/g) } \\
\hline $200 \mathrm{mg} / \mathrm{kg}$ & $359.51 \pm 47.36^{\text {cegh }}$ & $347.64 \pm 35.18^{\text {bcegh }}$ & $16.24 \pm 3.11^{\text {bcegh }}$ & $74.30 \pm 15.28^{\text {acegh }}$ \\
\hline $100 \mathrm{mg} / \mathrm{kg}$ & $326.73 \pm 55.75^{\text {acegh }}$ & $304.56 \pm 21.52^{\text {acegh }}$ & $18.28 \pm 3.02^{\text {acegh }}$ & $138.90 \pm 42.91^{\text {acegh }}$ \\
\hline $50 \mathrm{mg} / \mathrm{kg}$ & $309.44 \pm 16.61^{\text {acegh }}$ & $282.77 \pm 26.13^{\text {acfgh }}$ & $19.50 \pm 1.96^{\mathrm{acegh}}$ & $195.10 \pm 23.95^{\text {acegh }}$ \\
\hline
\end{tabular}

Values are expressed mean $\pm \mathrm{SD}$ of 10 rats. $\mathrm{AR}=$ Aqueous extracts of Achyranthis Radix $; \mathrm{OA}=$ Osteoarthritis; $\mathrm{EC}=$ Aqueous extracts of Eucommiae Cortex; $\mathrm{PCP}=$ Pomegranate Concentration Powder; $\mathrm{AC}=$ Articular cartilage; $\mathrm{SM}=$ Synovial membrane; $\mathrm{IF}=\mathrm{Inflammatory}$. ${ }^{a} p<0.01$ and ${ }^{b} p<0.05$ as compared with sham control; ${ }^{c} p<0.01$ and ${ }^{d} p<0.05$ as compared with OA control; ${ }^{\mathrm{e}} \mathrm{p}<0.01$ and ${ }^{\mathrm{f}} \mathrm{p}<0.05$ as compared with PCP single formula; ${ }^{\mathrm{g}} \mathrm{p}<0.01$ as compared with EC single formula; ${ }^{\mathrm{h}} \mathrm{p}<0.01$ as compared with AR single formula.

Table 13. Femur and Tibia AC with SM PARP-immunolabeled Cell Numbers in Sham-operated or OA Rats

\begin{tabular}{|c|c|c|c|}
\hline \multirow{2}{*}{ Groups } & \multicolumn{3}{|c|}{ PARP-immunolabeled cell numbers } \\
\hline & Femur AC & Tibia AC & SM \\
\hline \multicolumn{4}{|l|}{ Controls } \\
\hline Sham & $69.00 \pm 13.62$ & $59.30 \pm 17.26$ & $71.70 \pm 21.09$ \\
\hline $\mathrm{OA}$ & $468.50 \pm 80.74^{\mathrm{a}}$ & $415.20 \pm 75.04^{\mathrm{a}}$ & $993.10 \pm 217.55^{\text {a }}$ \\
\hline Diclofenac & $181.80 \pm 29.01^{\mathrm{ab}}$ & $192.30 \pm 50.30^{\mathrm{ab}}$ & $153.20 \pm 22.72^{\mathrm{ab}}$ \\
\hline \multicolumn{4}{|c|}{ Single formula $(200 \mathrm{mg} / \mathrm{kg})$} \\
\hline PCP & $251.50 \pm 46.79^{\mathrm{ab}}$ & $281.40 \pm 29.58^{\mathrm{ab}}$ & $336.10 \pm 100.58^{\mathrm{ab}}$ \\
\hline EC & $354.50 \pm 51.58^{\mathrm{ab}}$ & $302.70 \pm 50.47^{\mathrm{ab}}$ & $569.30 \pm 132.37^{\mathrm{ab}}$ \\
\hline AR & $330.00 \pm 39.68^{a b}$ & $281.20 \pm 26.12^{\mathrm{ab}}$ & $536.50 \pm 108.42^{a b}$ \\
\hline \multicolumn{4}{|c|}{ Mixed formula - PCP:EC:AR 5:4:1 (g/g) } \\
\hline $200 \mathrm{mg} / \mathrm{kg}$ & $98.00 \pm 20.02^{\text {abcde }}$ & $88.10 \pm 11.44^{\text {abcde }}$ & $109.00 \pm 31.47^{\text {abcde }}$ \\
\hline $100 \mathrm{mg} / \mathrm{kg}$ & $127.00 \pm 23.65^{\text {abcde }}$ & $133.90 \pm 36.46^{\text {abcde }}$ & $139.70 \pm 52.35^{\text {abcde }}$ \\
\hline $50 \mathrm{mg} / \mathrm{kg}$ & $170.30 \pm 26.17^{\text {abcde }}$ & $182.20 \pm 25.17^{\text {abcde }}$ & $161.40 \pm 29.21^{\text {abcde }}$ \\
\hline
\end{tabular}

Values are expressed mean $\pm \mathrm{SD}$ of 10 rats, cells $/ \mathrm{mm}^{2} . \mathrm{AR}=$ Aqueous extracts of Achyranthis Radix $; \mathrm{OA}=$ Osteoarthritis; $\mathrm{EC}=\mathrm{Aqueous}$ extracts of Eucommiae Cortex; $\mathrm{PCP}=$ Pomegranate Concentration Powder; AC = Articular cartilage; $\mathrm{SM}=$ Synovial membrane; $\mathrm{PARP}=$ Cleaved poly(ADP-ribose) polymerase. ${ }^{a} \mathrm{p}<0.01$ as compared with sham control; ${ }^{b} \mathrm{p}<0.01$ as compared with OA control; ${ }^{\mathrm{c}} \mathrm{p}<0.01$ as compared with PCP single formula; ${ }^{d} \mathrm{p}<0.01$ as compared with EC single formula; ${ }^{\mathrm{e}} \mathrm{p}<0.01$ as compared with AR single formula.

groups showed dose-dependent increases in the femoral and tibial AC thicknesses compared with the PCP, EC and AR single treatment groups. Significant increases in the number of inflammatory cells that infiltrated the SM were detected in the OA control group compared with the sham control group. Significant decreases in the number of inflammatory cells that infiltrated the SM were observed in the 200,100 , and $50 \mathrm{mg} / \mathrm{kg}$ 

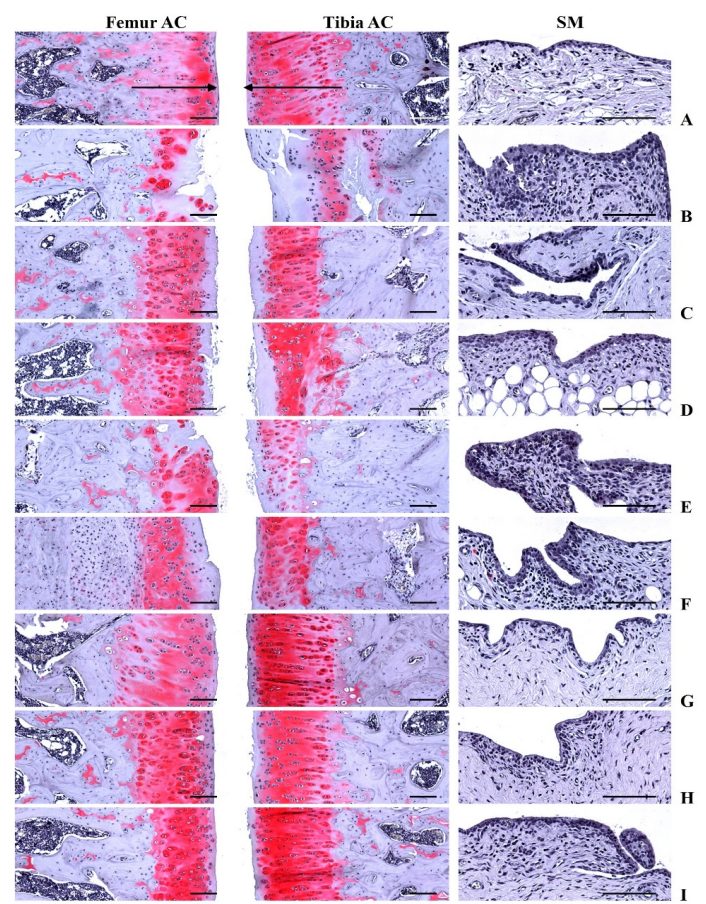

Fig. 8. Effect of mixed formulation (Pomegranate Concentration Powder (PCP): Aqueous extracts of Eucommiae Cortex (EC): Aqueous extracts Achyranthis Radix (AR) 5:4:1 (g/g) on the femur and tibia AC with $\mathrm{SM}$ in surgically induced osteoarthritis (OA). Histological images shown are representative of ten rats per each groups. (A), Sham vehicle control; (B), OA control; (C), OA-surgery+ diclofenac sodium $2 \mathrm{mg} / \mathrm{kg}$ subcutaneously; (D), OA-surgery+ $200 \mathrm{mg} / \mathrm{kg}$ PCP only; (E), OA-surgery+200 mg/kg EC only; (F), OA-surgery+200 $\mathrm{mg} / \mathrm{kg}$ AR only; (G), $200 \mathrm{mg} / \mathrm{kg}$ PCP:EC:AR 5:4:1 (g/g); (H), $100 \mathrm{mg} / \mathrm{kg}$ PCP:EC:AR 5:4:1 (g/g) mixed formula; (I), $50 \mathrm{mg} / \mathrm{kg}$ PCP:EC:AR 5:4:1 (g/g) mixed formula. Arrows indicated the thicknesses of tibia or femur AC or of SM lining epithelium. All Safranin O stain. Scale bars $=120 \mu \mathrm{m}$.

combination treatment groups compared with the $\mathrm{OA}$ control group (Fig 8, Table 12).

\section{Effects on the PARP-immunoreactive cells in the femoral and tibial $A C$ with SM}

The number of PARP-immunoreactive cells in the femoral and tibial AC with SM was significantly increased in the OA control group, while all test

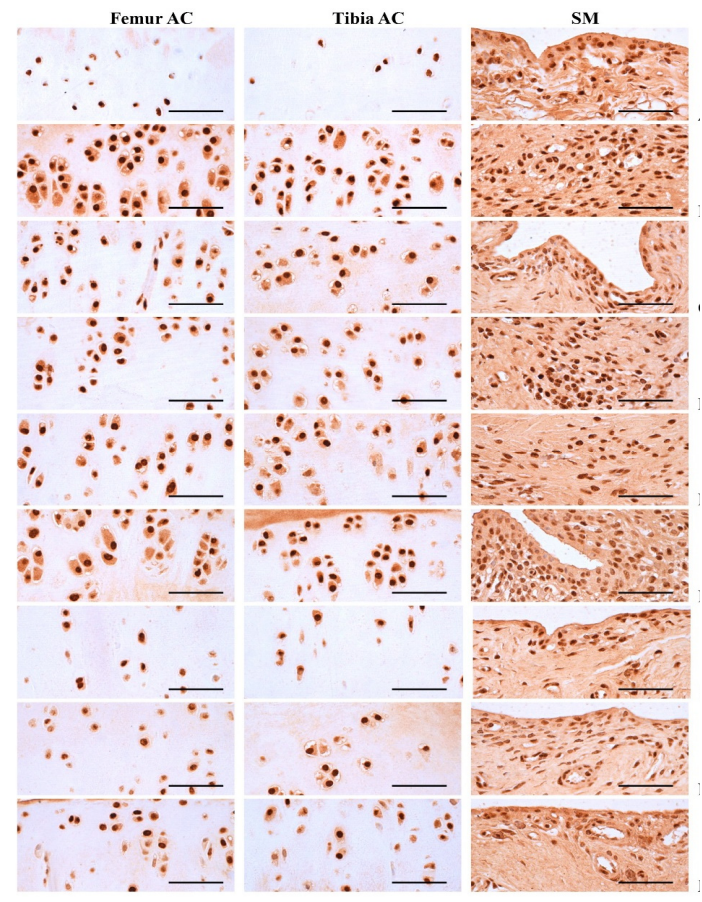

Fig. 9. Effect of mixed formulation (Pomegranate Concentration Powder (PCP): Aqueous extracts of Eucommiae Cortex (EC): Aqueous extracts Achyranthis Radix (AR) 5:4:1 (g/g) on Cleaved poly(ADP-ribose) polymerase (PARP)-immunoreactive cells on the femur and tibia Articular cartilage (AC) with Synovial membrane (SM) in surgically induced osteoarthritis (OA). Immunohistochemistrical images shown are representative of ten rats per each groups. (A), Sham vehicle control; (B), OA control; (C), OA-surgery+ diclofenac sodium $2 \mathrm{mg} / \mathrm{kg}$ subcutaneously; (D), OA-surgery+ $200 \mathrm{mg} / \mathrm{kg}$ PCP only; (E), $\mathrm{OA}$-surgery+200 mg/kg EC only; (F), OA-surgery+200 mg/kg AR only; (G), $200 \mathrm{mg} / \mathrm{kg}$ PCP:EC:AR 5:4:1 (g/g); (H), 100 $\mathrm{mg} / \mathrm{kg}$ PCP:EC:AR 5:4:1 (g/g) mixed formula; (I), $50 \mathrm{mg} / \mathrm{kg}$ PCP:EC:AR 5:4:1 $(\mathrm{g} / \mathrm{g})$ mixed formula. ABC, Avidin-biotin complex. All $A B C$ immunostain. Scale bars $=120 \mu \mathrm{m}$.

substance-treated groups showed significant decreases in PARP immunoreactivity compared with the control groups. In particular, the 200,100 , and $50 \mathrm{mg} / \mathrm{kg}$ combination treatment groups showed significant, dose-dependent decreases in the number of PARP-immunolabeled cells in the femoral and tibial $\mathrm{AC}$, and SM compared with the PCP, EC and AR single treatment groups (Fig 9, Table 13). 
Table 14. Femur and Tibia AC with SM COX-2-immunostained Cell Numbers in Sham-operated or OA Rats

\begin{tabular}{lccc}
\hline & \multicolumn{3}{c}{ COX-2-immunostained cell numbers } \\
Groups & Femur AC & Tibia AC & SM \\
\cline { 2 - 4 } Controls & & & $22.50 \pm 9.52$ \\
Sham & $65.70 \pm 16.71$ & $96.50 \pm 32.30$ & $478.30 \pm 119.79^{\text {a }}$ \\
OA & $398.70 \pm 115.55^{\text {a }}$ & $359.70 \pm 53.47^{\text {a }}$ & $137.30 \pm 38.62^{\text {ac }}$ \\
Diclofenac & $142.40 \pm 29.31^{\text {ac }}$ & $143.50 \pm 26.87^{\text {ac }}$ & $306.80 \pm 47.80^{\text {ac }}$ \\
Single formula $(200 \mathrm{mg} / \mathrm{kg})$ & & & $343.00 \pm 52.93^{\text {ac }}$ \\
PCP & $238.40 \pm 37.46^{\text {ac }}$ & $205.10 \pm 42.04^{\text {ac }}$ & $354.90 \pm 57.22^{\text {ac }}$ \\
EC & $261.80 \pm 36.14^{\text {ac }}$ & $261.80 \pm 24.27^{\text {ac }}$ & \\
AR & $271.90 \pm 35.78^{\text {ac }}$ & $246.10 \pm 24.12^{\text {ac }}$ & \\
Mixed formula - PCP:EC:AR 5:4:1 (g/g) & $87.30 \pm 15.36^{\text {acdef }}$ & $103.40 \pm 15.32^{\text {cdef }}$ & $99.80 \pm 14.01^{\text {acdef }}$ \\
$200 \mathrm{mg} / \mathrm{kg}$ & $130.60 \pm 28.98^{\text {acdef }}$ & $121.20 \pm 19.44^{\text {bcdef }}$ & $94.00 \pm 14.55^{\text {acdef }}$ \\
$100 \mathrm{mg} / \mathrm{kg}$ & $140.90 \pm 21.65^{\text {acdef }}$ & $144.10 \pm 26.95^{\text {acdef }}$ & $133.40 \pm 28.92^{\text {acdef }}$ \\
$50 \mathrm{mg} / \mathrm{kg}$ & & & \\
\hline
\end{tabular}

Values are expressed mean $\pm \mathrm{SD}$ of 10 rats, cells $/ \mathrm{mm}^{2} . \mathrm{AR}=$ Aqueous extracts of Achyranthis Radix $; \mathrm{OA}=$ Osteoarthritis; $\mathrm{EC}=\mathrm{Aqueous}$ extracts of Eucommiae Cortex; $\mathrm{PCP}=$ Pomegranate Concentration Powder; AC = Articular cartilage; $\mathrm{SM}=$ Synovial membrane; $\mathrm{COX}=$ Cyclooxygenase. ${ }^{\mathrm{a}} \mathrm{p}<0.01$ and ${ }^{\mathrm{b}} \mathrm{p}<0.05$ as compared with sham control; ${ }^{\mathrm{c}} \mathrm{p}<0.01$ as compared with OA control; ${ }^{\mathrm{d}} \mathrm{p}<0.01$ as compared with PCP single formula; ${ }^{e} \mathrm{p}<0.01$ as compared with EC single formula; ${ }^{\mathrm{f}} \mathrm{p}<0.01$ as compared with AR single formula.

Table 15. Femur and Tibia AC with SM TNF- $\alpha$-immunopositive Cell Numbers in Sham-operated or OA Rats

\begin{tabular}{lccc}
\hline & & TNF- $\alpha$-immunopositive cell numbers & SM \\
\cline { 2 - 3 } Groups & Femur AC & Tibia AC & $16.10 \pm 4.63$ \\
\hline Controls & $63.80 \pm 14.41$ & $43.40 \pm 12.15$ & $583.70 \pm 85.67^{\text {a }}$ \\
Sham & $309.90 \pm 73.26^{\text {a }}$ & $307.60 \pm 23.06^{\text {a }}$ & $218.10 \pm 38.43^{\text {ab }}$ \\
OA & $144.50 \pm 33.01^{\text {ab }}$ & $150.30 \pm 28.82^{\text {ab }}$ & \\
Diclofenac & & & $297.70 \pm 46.82^{\text {ab }}$ \\
Single formula $(200 \mathrm{mg} / \mathrm{kg})$ & $193.00 \pm 23.96^{\text {ab }}$ & $230.40 \pm 43.21^{\text {ab }}$ & $327.50 \pm 54.02^{\text {ab }}$ \\
PCP & $216.90 \pm 37.79^{\text {ab }}$ & $255.50 \pm 40.60^{\text {ab }}$ & $321.00 \pm 78.56^{\text {ab }}$ \\
EC & $234.80 \pm 35.25^{\text {ab }}$ & $256.20 \pm 47.66^{\text {ab }}$ & \\
AR & & & $44.70 \pm 13.90^{\text {abcde }}$ \\
Mixed formula - PCP:EC:AR 5:4:1 $(\mathrm{g} / \mathrm{g})$ & $67.90 \pm 15.36^{\text {abcde }}$ & $87.20 \pm 19.11^{\text {abcde }}$ \\
$200 \mathrm{mg} / \mathrm{kg}$ & $89.80 \pm 12.05^{\text {abcde }}$ & $130.70 \pm 20.15^{\text {abcde }}$ & $178.60 \pm 43.63^{\text {abcde }}$ \\
$100 \mathrm{mg} / \mathrm{kg}$ & $119.00 \pm 25.22^{\text {abcde }}$ & $153.00 \pm 14.67^{\text {abcde }}$ & \\
$50 \mathrm{mg} / \mathrm{kg}$ & $154.60 \pm 24.42^{\text {abcde }}$ & & \\
\hline
\end{tabular}

Values are expressed mean $\pm \mathrm{SD}$ of 10 rats, cells $/ \mathrm{mm}^{2}$. $\mathrm{AR}=$ Aqueous extracts of Achyranthis Radix; $\mathrm{OA}=$ Osteoarthritis; $\mathrm{EC}=\mathrm{Aqueous}$ extracts of Eucommiae Cortex; $\mathrm{PCP}=$ Pomegranate Concentration Powder; $\mathrm{AC}=$ Articular cartilage; $\mathrm{SM}=\mathrm{Synovial}$ membrane; $\mathrm{TNF}=$ Tumor necrosis factor. ${ }^{\mathrm{a}} \mathrm{p}<0.01$ as compared with sham control; ${ }^{\mathrm{b}} \mathrm{p}<0.01$ as compared with OA control; ${ }^{\mathrm{c}} \mathrm{p}<0.01$ as compared with PCP single formula; ${ }^{\mathrm{d}} \mathrm{p}<0.01$ as compared with EC single formula; ${ }^{\mathrm{e}} \mathrm{p}<0.01$ as compared with AR single formula.

\section{Effects on COX-2 and TNF- $\alpha$} immunoreactive cells in the femoral and tibial AC with SM

Significant increases in the number of femoral and tibial AC SM COX-2 and TNF- $\alpha$-immunoreactive cells were detected in the OA control group. Conversely, COX-2- and TNF- $\alpha$-immunoreactive cells of the femoral and tibial AC, and SM were significantly lower in all test substance-treated groups when compared with the OA control group. Of note, the 200, 100 and 50 
$\mathrm{mg} / \mathrm{kg}$ combination treatment groups showed significant decreases in the number of COX-2- and TNF- $\alpha$ -immunolabeled cells in the femoral and tibial AC, and SM, compared with the PCP, EC and AR single treatment groups (Fig 10 and 11, Table 14 and 15)).

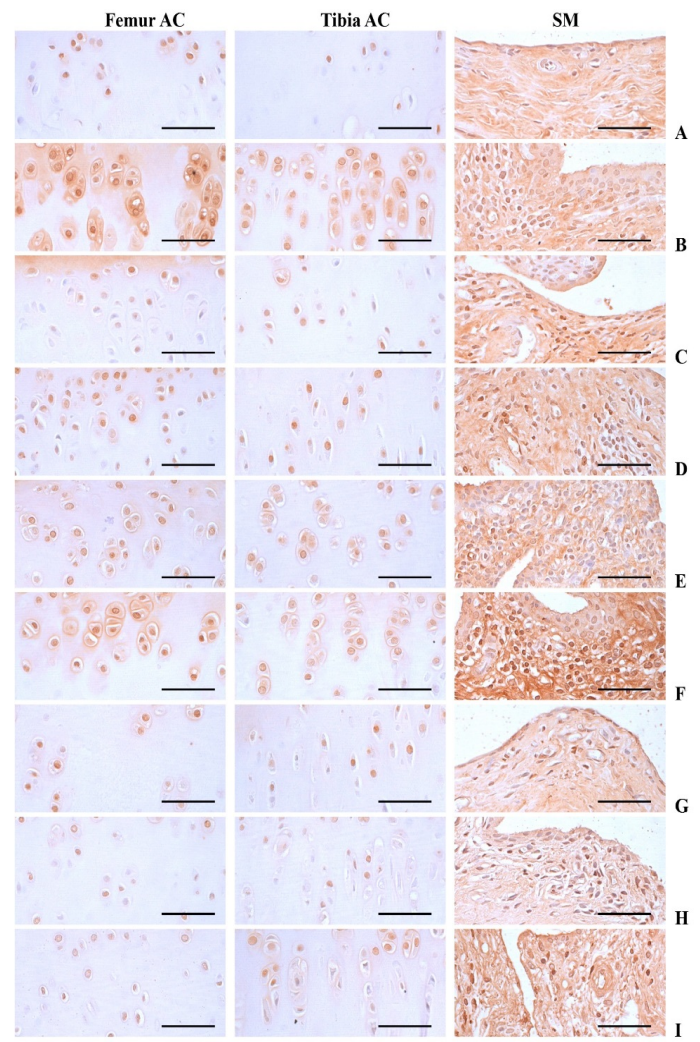

Fig. 10. Effect of mixed formulation (Pomegranate Concentration Powder (PCP): Aqueous extracts of Eucommiae Cortex (EC): Aqueous extracts Achyranthis Radix (AR) 5:4:1 (g/g) on the Cyclooxygenase (COX-2)-immunoreactive cells on the femur and tibia AC with SM, on the femur and tibia Articular cartilage (AC) with Synovial membrane (SM) in surgically induced osteoarthritis (OA). Immunohistochemistrical images shown are representative of ten rats per each groups. (A), Sham vehicle control; (B), OA control; (C), $\mathrm{OA}$-surgery+ diclofenac sodium $2 \mathrm{mg} / \mathrm{kg}$ subcutaneously; (D), OA-surgery+ $200 \mathrm{mg} / \mathrm{kg}$ PCP only; (E), OA-surgery+200 mg/kg EC only; (F), OA-surgery+200 $\mathrm{mg} / \mathrm{kg}$ AR only; (G), $200 \mathrm{mg} / \mathrm{kg}$ PCP:EC:AR 5:4:1 (g/g); (H), $100 \mathrm{mg} / \mathrm{kg}$ PCP:EC:AR 5:4:1 $(\mathrm{g} / \mathrm{g})$ mixed formula; (I), $50 \mathrm{mg} / \mathrm{kg}$ PCP:EC:AR 5:4:1 (g/g) mixed formula. ABC, Avidin-biotin complex. All ABC immunostain. Scale bars $=120 \mu \mathrm{m}$.

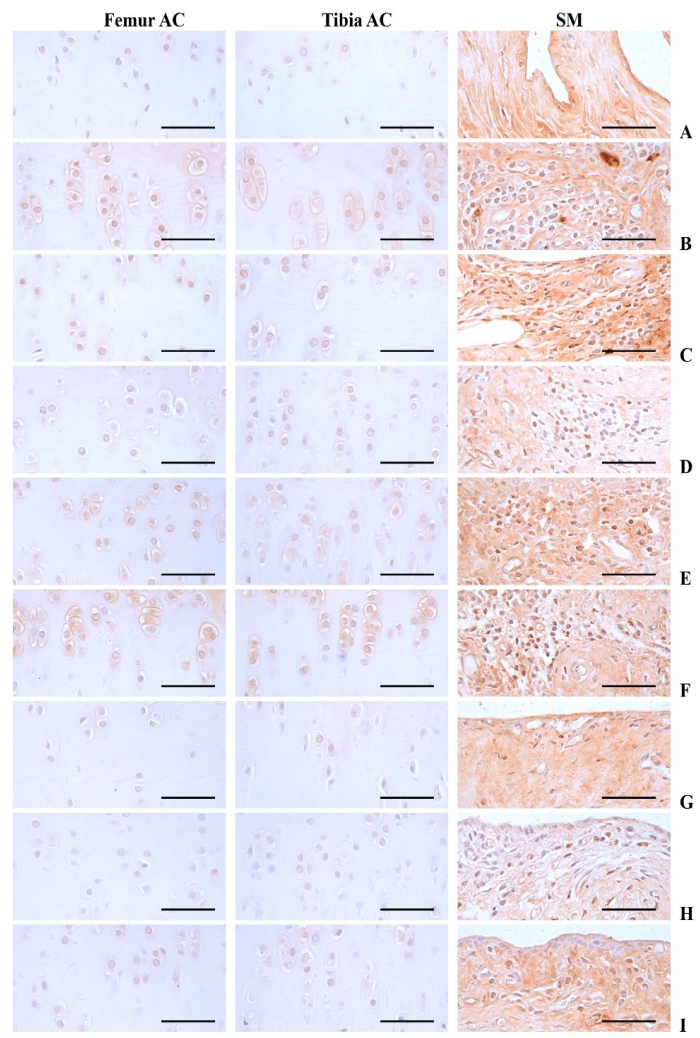

Fig. 11. Effect of mixed formulation (Pomegranate Concentration Powder (PCP): Aqueous extracts of Eucommiae Cortex (EC): Aqueous extracts Achyranthis Radix (AR) 5:4:1 (g/g) on the Tumor necrosis factor (TNF)$\alpha$-immunoreactive cells on the femur and tibia $A C$ with SM, on the femur and tibia Articular cartilage (AC) with Synovial membrane (SM) in surgically induced osteoarthritis (OA). Immunohistochemistrical images shown are representative of ten rats per each groups. (A), Sham vehicle control; (B), OA control; (C), OA-surgery+ diclofenac sodium $2 \mathrm{mg} / \mathrm{kg}$ subcutaneously; (D), OA-surgery+ $200 \mathrm{mg} / \mathrm{kg}$ PCP only; (E), OA-surgery+200 mg/kg EC only; (F), OA-surgery+200 $\mathrm{mg} / \mathrm{kg}$ AR only; (G), $200 \mathrm{mg} / \mathrm{kg}$ PCP:EC:AR 5:4:1 (g/g); (H), $100 \mathrm{mg} / \mathrm{kg}$ PCP:EC:AR 5:4:1 $(\mathrm{g} / \mathrm{g})$ mixed formula; (I), $50 \mathrm{mg} / \mathrm{kg}$ PCP:EC:AR 5:4:1 (g/g) mixed formula. ABC, Avidin-biotin complex. All ABC immunostain. Scale bars $=120 \mu \mathrm{m}$. 


\section{Discussion}

Several previous studies have reported that PCP, $\mathrm{EC}$ and $\mathrm{AR}$ have individual disease-modifying effects against $\mathrm{OA}^{15-17), 26), 27), 29), 30)}$. Furthermore, our previous in vitro studies showed that pretreatment with $\mathrm{PCP}$, EC and AR $(1 \mathrm{mg} / \mathrm{mL})$ inhibited inflammatory damage to chondrocytes by lipopolysaccharide and ECM degradation induced by recombinant human IL- $1 \alpha^{35}$. An in vivo study ${ }^{36)}$ showed that a PCP:EC:AR ratio of 5:4:1 had the highest inhibitory activity against surgically induced OA among nine mixed formulations of PCP with EC and AR. Nevertheless, our previous study focused on determining the appropriate proportions for further examining the effects of the PCP:EC:AR 5:4:1 (g/g) mixed formula. Dose-response information is necessary for the safe and effective use of a novel formula. Thus, to obtain additional information, this study examined the dose-dependent anti-OA potential of the 5:4:1 (g/g) PCP:EC:AR formulation on rats with surgically induced OA.

$\mathrm{OA}$ is a type of chronic degenerative inflammatory disease that results from the destruction of joint cartilage. During the progression of OA, cartilage damage can induce the release of leukotrienes, potent inflammatory mediators, by increasing COX-2 and 5-LPO activity, coordinated by IL-1 and TNF- $\alpha$. IL-1 and TNF- $\alpha$ increase the production of $\mathrm{NO}$ and $\mathrm{PGE}_{2}$, disrupting the ability of chondrocytes to maintain cartilage homeostasis ${ }^{48)}$. These acute inflammatory factors contribute to the increase in joint thickness and abnormal bone growth of painful osteophytes, and edematous changes to the surrounding tissue ${ }^{13), 49-51)}$. Conversely, suppressing these inflammatory factors ameliorates OA symptoms. As a result, OA control rats showed an increase in knee thickness. In addition, decreases in the femoral and tibial AC thickness were detected. The number of COX-2- and TNF- $\alpha$-immunolabeled cells increased, along with an increase in $\mathrm{PGE}_{2}$ and LPO activity. However, these alterations were inhibited by the PCP:EC:AR 5:4:1 (g/g) combination in a dose-dependent manner. The $50 \mathrm{mg} / \mathrm{kg}$ PCP:EC:AR 5:4:1 (g/g) mixed formula showed favorable anti-inflammatory activity comparable to $2 \mathrm{mg} / \mathrm{kg}$ diclofenac, and was more potent than $200 \mathrm{mg} / \mathrm{kg} \mathrm{PCP}$, $\mathrm{EC}$ or AR used alone. These results support that the PCP:EC:AR 5:4:1 (g/g) formula effectively inhibited OA by inhibiting inflammatory activity in rats with surgically induced OA.

Physical injuries can cause the loss of a joint region, cartilage erosion and osteophyte formation. These changes can been observed by gross observation and $\mathrm{X}$-ray images ${ }^{37,52)}$, and are considered a reasonable index for measuring the efficacy of anti-OA drugs ${ }^{53), 54)}$. BMD is used as a predictor of bone disease susceptibility $^{55), 56)}$ as well as for information regarding bone quality in osteoporosis treatment trials ${ }^{57)}$. Additionally, the measurement of focal BMDs and bone strength can be used to estimate the extent of OA progression $^{58-61)}$. As a result, we observed loss of the knee joint region, femoral and tibial $\mathrm{AC}$ erosion, and osteophyte formation in OA control rats through DEXA image analysis. In addition, corresponding significant decreases in the focal BMD of the total knee joint, and the femoral and tibial AC surface regions were observed concomitantly with the decrease in femoral and tibial $\mathrm{AC}$ focal $\mathrm{CS}$ in the $\mathrm{OA}$ control group compared with the sham control group. Surgically induced OA-related focal loss of $\mathrm{AC}$, osteophyte formation and decreased BMD and $\mathrm{CS}$ in OA-model rats were dose-dependently inhibited by treatment with the 200, 100 and $50 \mathrm{mg} / \mathrm{kg}$ PCP:EC:AR 5:4:1 (g/g) combination. We speculate that the surface cartilage CS may be involved in the formation of a component of the ECM and conditioning of chondrocytes. Healthy ECM and chondrocytes improve compressive strength. 
MMPs are pivotal proteolytic enzymes involved in deconstructing chondrocytes and bony tissue. Under normal conditions, MMPs are suppressed by the tissue inhibitor of metalloproteinase system ${ }^{62}$. MMPs act as proteases that degrade the $\mathrm{ECM}$, predominately $\mathrm{PG}^{63)}$, and are responsible for the destruction of cartilage components. Thus, inhibiting MMPs is a reasonable strategy to treat $\mathrm{OA}^{7,64)}$. The induction of $\mathrm{OA}$ by surgery increased the MMP-2 and -9 activity in the femoral and tibial $\mathrm{AC}$, and $\mathrm{SM}$, while the combination treatment dose-dependently suppressed these alterations. These results indicate that PCP:EC:AR 5:4:1 (g/g) will potentially be useful to treat OA.

An important indicator of $\mathrm{OA}$ is fibrosis, resulting in joint stiffness and pain. Fibrosis is defined as the excessive accumulation of connective tissue, potentially leading to organ malfunction. The maximum extension angle of a joint is used as a measure of its stiffness. $0^{\circ}$ indicates the maximum extension. The lower the value, the better the knee function ${ }^{34), 37-39), 43)}$. The maximum extension angles in knees of OA rats were dose-dependently increased by 200,100 or $50 \mathrm{mg} / \mathrm{kg}$ PCP:EC:AR 5:4:1 (g/g) treatment. In addition, OA-induced hypertrophy and hyperplasia of the SM were also dose-dependently inhibited by 200,100 and $50 \mathrm{mg} / \mathrm{kg}$ PCP:EC:AR 5:4:1 (g/g). Our results indicate that PCP:EC:AR 5:4:1 (g/g) synergistically ameliorated OA-related joint stiffness.

The Mankin scoring system is widely accepted as a histopathological method to examine AC damage, including cartilage surface damage, decreased chondrocyte numbers, clone formation and Safranin-O stain intensity. In this system, the higher the score, the higher the level of $\mathrm{OA}^{34), 37-39), 43), 65)}$. Decreases in $\mathrm{AC}$ thickness are consistently detected in OA model animals $^{34), 37-39), 66-68)}$. We observed that the Mankin scores dose-dependently decreased in response to treatment with the PCP:EC:AR 5:4:1 (g/g) mixed formula for both the femoral and tibial $\mathrm{AC}$ compared with the OA control group. The extent of OA-decreased femoral and tibial AC thickness was also ameliorated in PCP:EC:AR 5:4:1 ( $\mathrm{g} / \mathrm{g})$ combination-treated rats compared with the OA control rats. As the PCP:EC:AR $5: 4: 1(\mathrm{~g} / \mathrm{g})$ combination dose-dependently decreased OA-related joint stiffness, it suggests that the combination could be suitable to relieve OA symptoms.

Apoptosis is a regulated form of cell death involved in development, homeostasis and aging ${ }^{69-71)}$. Chondrocytes are the only cell type in the $\mathrm{AC}^{72)}$, so the dysregulation of chondrocyte death and survival can lead to the disintegration of the $\mathrm{AC}^{73), 74)}$. In the current study, PARP was selected as an apoptotic marker. The PARP immunoreactivity increased in the femoral and tibial $\mathrm{AC}$, and $\mathrm{SM}$, after OA surgery. Treatment with the PCP:EC:AR 5:4:1 (g/g) combination dose-dependently decreased OA-induced PARP immunoreactivity. The inhibition of apoptosis by PCP:EC:AR 5:4:1 $(\mathrm{g} / \mathrm{g})$ is evidence of its protective effect against $\mathrm{OA}$.

BrdU immunohistochemistry can be used to detect chondrocyte proliferation in cartilage ${ }^{66), 75)}$. When the chondrocytes have proliferative capacity, the cell will uptake $\mathrm{BrdU}{ }^{34), 37-39), 66)}$. BrdU-immunoreactivity was significantly reduced in the femoral and tibial $\mathrm{AC}$ of the OA control group, indicating the inhibition of OA-related chondrocyte proliferation. The number of BrdU-positive chondrocytes in the sham control group was significantly lower than in the OA control group, indicating OA-associated fibrosis and hyperplasia at the SM. However, the number of BrdU-immunostained cells notably increased in response to the 200, 100 and $50 \mathrm{mg} / \mathrm{kg}$ PCP:EC:AR 5:4:1 (g/g) combination treatments in both femoral and tibial $\mathrm{AC}$, but decreased in the SM. The enhancement of chondrocyte proliferation by PCP:EC:AR 5:4:1 (g/g) treatment suggests that PCP:EC:AR 5:4:1 $(\mathrm{g} / \mathrm{g})$ is a promising 
agent for the treatment of OA.

$\mathrm{AC}$ must tolerate repetitive physical stress on the human body. It is connective tissue composed of chondrocytes within an ECM of collagen, PG, aggrecan and $\mathrm{SOX} 9^{6,7)}$. Changes in the ECM are a major feature in the pathogenesis of OA. AC is damaged by physical force, loses PG content, and undergoes swelling and hypertrophy. Chondrocytes release degradative enzymes when they detect these changes in the ECM. ECM degradation is associated with inflammation, chondrocyte death and damage leading to the failure of the maintenance and function of $\mathrm{AC}^{76}$. The transcription factor SOX9 plays an important role in chondrogenic differentiation ${ }^{77)}$. Collagen and aggrecan in the ECM are key components of healthy cartilage $e^{45}$. Therefore, preventing ECM degradation is a relevant approach for the treatment of $\mathrm{OA}^{44), 45), 78)}$. Treatments with the PCP:EC:AR 5:4:1 (g/g) combination dose-dependently downregulated the OA-associated reduction in the transcript levels of collagen type II, and increased the transcript levels of chondrogenic genes in the SM. All doses of the combined treatment significantly increased the ECM formation-related factors in the rats with surgically induced OA when compared with each individual treatment. These results suggest that the PCP:EC:AR 5:4:1 (g/g) formula facilitated ECM formation in rats with surgically induced $\mathrm{OA}$.

\section{Conclusion}

The results of this study suggest that the PCP:EC:AR $5: 4: 1(\mathrm{~g} / \mathrm{g})$ combination synergistically increased the anti-OA effects of each ingredient through anti-inflammatory and chondrogenic activity in rats with surgically induced OA. 200, 100 and $50 \mathrm{mg} / \mathrm{kg}$ PCP:EC:AR 5:4:1 (g/g) treatments showed dose-dependent inhibitory activity against OA-related signs compared with $200 \mathrm{mg} / \mathrm{kg}$ PCP, EC or AR. The $50 \mathrm{mg} / \mathrm{kg}$ PCP:EC:AR 5:4:1 (g/g) treatment showed similar protective effects on the AC to $2 \mathrm{mg} / \mathrm{kg}$ diclofenac. Therefore, it is expected that the PCP:EC:AR 5:4:1 (g/g) combination formula is a promising new potent $\mathrm{AC}$-protective agent for relieving various signs of $\mathrm{OA}$.

\section{Acknowledgements}

This research was supported by the Foundation of Agri. Tech. Commericalization \& Transfer(FACT) through the R \& D Results Commericalization Support Project(NO. PJ011566) on 2015.

\section{References}

1. Dougados M, Nguyen M, Berdah L, Mazières B, Vignon E, Lequesne M, et al. Evaluation of the structure-modifying effects of diacerein in hip osteoarthritis: ECHODIAH, a three-year, placebocontrolled trial. Evaluation of the Chondromodulating Effect of Diacerein in OA of the Hip. Arthritis and rheumatism. 2001;44(11):2539-2547.

2. Tamura T, Ohmori K. Rhein, an active metabolite of diacerein, suppresses the interleukin-lalpha-induced proteoglycan degradation in cultured rabbit articular chondrocytes. Japanese journal of pharmacology. 2001;85(1):101-104.

3. Krabbe KS, Pedersen $M$, Bruunsgaard $H$. Inflammatory mediators in the elderly. Experimental gerontology. 2004;39(5):687-699.

4. Cesari M, Penninx BW, Pahor M, Lauretani F, Corsi AM, Rhys Williams G, et al. Inflammatory markers and physical performance in older persons: the InCHIANTI study. The journals of gerontology Series A, Biological sciences and medical sciences. 2004;59(3):242-248.

5. Morrisette-Thomas V, Cohen AA, Fülöp T, Riesco 
Anti-osteoarthritic effects of a combination of pomegranate concentrate powder, Eucommiae cortex and Achyranthis radix in rats

É, Legault V, Li Q, et al. Inflamm-aging does not simply reflect increases in pro-inflammatory markers. Mechanisms of ageing and development. 2014;139:49-57.

6. Qin J, Liu YS, Liu J, Li J, Tan Y, Li XJ, et al. Effect of Angelica sinensis Polysaccharides on Osteoarthritis In Vivo and In Vitro: A Possible Mechanism to Promote Proteoglycans Synthesis. Evidence-based complementary and alternative medicine : eCAM. 2013;2013:794761.

7. Na JY, Song KB, Kim SH, Kwon YB, Kim DG, Lee JK, et al. Effects of HPL-04 on Degenerative Osteoarthritis. J Korean Soc Food Sci Nutr. 2014;43(1):30-39.

8. Goldring MB, Goldring SR. Osteoarthritis. Journal of cellular physiology. 2007;213(3):626-634.

9. Buckwalter JA, Mankin HJ, Grodzinsky AJ. Articular cartilage and osteoarthritis. Instructional course lectures. 2005;54:465-480.

10. Martin JA, Buckwalter JA. Aging, articular cartilage chondrocyte senescence and osteoarthritis. Biogerontology. 2002;3(5):257-264.

11. Sandell LJ, Aigner T. Articular cartilage and changes in arthritis. An introduction: cell biology of osteoarthritis. Arthritis research. 2001;3(2):107-113.

12. Appleton CT, McErlain DD, Pitelka V, Schwartz $\mathrm{N}$, Bernier SM, Henry JL, et al. Forced mobilization accelerates pathogenesis: characterization of a preclinical surgical model of osteoarthritis. Arthritis research \& therapy. 2007;9(1):R13.

13. Nam DE, Kim OK, Shim TJ, Kim JH, Lee J. Effect of Boswellia serrata extracts on degenerative osteoarthritis in vitro and in vivo models. J Korean Soc Food Sci Nutr. 2014;43(5):631-640.

14. Gil MI, Tomás-Barberán FA, Hess-Pierce B, Holcroft DM, Kader AA. Antioxidant activity of pomegranate juice and its relationship with phenolic composition and processing. Journal of agricultural and food chemistry. 2000;48(10):4581-4589.

15. Ahmed S, Wang N, Hafeez BB, Cheruvu VK, Haqqi TM. Punica granatum L. extract inhibits IL-1beta-induced expression of matrix metalloproteinases by inhibiting the activation of MAP kinases and NF-kB in human chondrocytes in vitro. The Journal of nutrition. 2005;135(9):2096-2102.

16. Shukla M, Gupta K, Rasheed Z, Khan KA, Haqqi TM. Bioavailable constituents/metabolites of pomegranate (Punica granatum L) preferentially inhibit COX2 activity ex vivo and IL-1beta-induced $\mathrm{PGE}_{2}$ production in human chondrocytes in vitro. Journal of inflammation (London, England). 2008;5:9.

17. Hadipour-Jahromy M, Mozaffari-Kermani R. Chondroprotective effects of pomegranate juice on monoiodoacetate-induced osteoarthritis of the knee joint of mice. Phytotherapy research : PTR. 2010;24(2):182-185.

18. Rasheed Z, Akhtar N, Haqqi TM. Pomegranate extract inhibits the interleukin-1 $\beta$-induced activation of MKK-3, p38 $\alpha$-MAPK and transcription factor RUNX-2 in human osteoarthritis chondrocytes. Arthritis research \& therapy. 2010;12(5):R195.

19. Kang SJ, Choi BR, Kim SH, Yi HY, Park HR, Kim DC, et al. Dried pomegranate potentiates anti-osteoporotic and anti-obesity activities of red clover dry extracts in ovariectomized rats. Nutrients. 2015;7(4):2622-2647.

20. Kang SJ, Choi BR, Lee EK, Kim SH, Yi HY, Park HR, et al. Inhibitory Effect of Dried Pomegranate Concentration Powder on Melanogenesis in B16F10 Melanoma Cells; Involvement of p38 and PKA Signaling Pathways. International journal of molecular sciences. 2015;16(10):24219-24242. 
21. Kang SJ, Choi BR, Kim SH, Yi HY, Park HR, Song $\mathrm{CH}$, et al. Anti-climacterium effects of pomegranate concentrated solutions in ovariectomized ddY mice. Experimental and therapeutic medicine. 2017;13(4):1249-1266.

22. Kang SJ, Choi BR, Kim SH, Yi HY, Park HR, Song $\mathrm{CH}$, et al. Beneficial effects of dried pomegranate juice concentrated powder on ultraviolet B-induced skin photoaging in hairless mice. Experimental and therapeutic medicine. 2017;14(2):1023-1036.

23. Hsieh CL, Yen GC. Antioxidant actions of Du-zhong (Eucommia ulmoides oliv.) toward oxidative damage in biomolecules. Life Sciences. 2000;66(15):1387-1400.

24. Kwan CY, Chen CX, Deyama T, Nishibe S. Endothelium-dependent vasorelaxant effects of the aqueous extracts of the Eucommia ulmoides Oliv. leaf and bark: implications on their antihypertensive action. Vascular pharmacology. 2003;40(5):229-235.

25. Zhao Y, Li Y, Wang X, Sun W. The experimental study of Cortex Eucommiae on meridian tropsim: the distribution study of aucubin in rat tissues. Journal of pharmaceutical and biomedical analysis. 2008;46(2):368-373.

26. Eum HA, Lee WY, Kim SH, Kim JY, Park SW, Lee JS, et al. Anti-inflammatory activity of CML-1: an herbal formulation. The American journal of Chinese medicine. 2005;33(1):29-40.

27. Lee SY, Kwon HK, Lee SM. SHINBARO, a new herbal medicine with multifunctional mechanism for joint disease: first therapeutic application for the treatment of osteoarthritis. Archives of pharmacal research. 2011;34(11):1773-1777.

28. Li J, Li HJ, Li P, Qi H. Simultaneous qualitation and quantification of four phytoecdysones in Radix Achyranthis Bidentatae by high-performance liquid chromatography with diode array detection.
Biomedical chromatography : BMC. 2007;21(8):823-828.

29. Yu F, Li X, Cai L, Li H, Chen J, Wong X, et al. Achyranthes bidentata polysaccharides induce chondrocyte proliferation via the promotion of the G1/S cell cycle transition. Molecular medicine reports. 2013;7(3):935-940.

30. Weng X, Lin P, Liu F, Chen J, Li H, Huang L, et al. Achyranthes bidentata polysaccharides activate the $\mathrm{Wnt} / \mathrm{b}$-catenin signaling pathway to promote chondrocyte proliferation. International journal of molecular medicine. 2014;34(4):1045-1050.

31. Lee HS, Kim HH, Ku SK. Hepatoprotective effects of Artemisiae capillaris herba and Picrorrhiza rhizoma combinations on carbon tetrachloride-induced subacute liver damage in rats. Nutrition research (New York, NY). 2008;28(4):270-277.

32. Choi JS, Kim JW, Kim KY, Cho HR, Choi IS, $\mathrm{Ku}$ SK. Antiosteoporotic effects of Polycan in combination with calcium lactate-gluconate in ovariectomized rats. Experimental and therapeutic medicine. 2014;8(3):957-967.

33. Choi JS, Kim JW, Kim KY, Lee JK, Sohn JH, $\mathrm{Ku}$ SK. Synergistic effect of fermented rice extracts on the probiotic and laxative properties of yoghurt in rats with loperamide-induced constipation. Evidence-based complementary and alternative medicine : eCAM. 2014;2014:878503.

34. Choi JS, Shin HS, Kim KY, Ku SK, Choi IS, Kim JW. Effect of Polycalcium, a mixture of Polycan and calcium lactate-gluconate in a 1:9 weight ratio, on rats with surgery-induced osteoarthritis. Experimental and therapeutic medicine. 2015;9(5):1780-1790.

35. Choi BR, Ku SK, Kang SJ, Park HR, Sung MS, Lee YJ, et al. Anti-osteoarthritis effects of Pomegranate, Eucommiae cortex and Achyranthis radix extracts on the primary cultured rat articular 
Anti-osteoarthritic effects of a combination of pomegranate concentrate powder, Eucommiae cortex and Achyranthis radix in rats

chondrocytes. Journal of Society of Preventive Korean Medicine. 2017;21(3):87-98.

36. Choi BR, Ku SK, Kang SJ, Park HR, Sung MS, Lee YJ, et al. Selection of the optimal herbal composition of pomegranate concentrated powder from aqueous extracts of Eucommiae Cortex and Achyranthis Radix to treat osteoarthritis in rats. J Korean Med. 2017;38(4):11-40.

37. Kim JW, Cho HR, Ku SK. Efficacy test of Polycan, a beta-glucan originated from Aureobasidium pullulans SM-2001, on anterior cruciate ligament transection and partial medial meniscectomy-induced-osteoarthritis rats. Journal of microbiology and biotechnology. 2012;22(2):274-282.

38. Kang SJ, Kim JW, Kim KY, Ku SK, Lee YJ. Protective effects of calcium gluconate on osteoarthritis induced by anterior cruciate ligament transection and partial medial meniscectomy in Sprague-Dawley rats. Journal of orthopaedic surgery and research. 2014;9(1):14.

39. Moon $\mathrm{CH}$, Kwon $\mathrm{O}$, Woo $\mathrm{CH}$, Ahn HD, Kwon YS, Park SJ, et al. Therapeutic effect of irradiation of magnetic infrared laser on osteoarthritis rat model. Photochemistry and photobiology. 2014;90(5):1150-1159.

40. van Ginhoven TM, Mitchell JR, Verweij M, Hoeijmakers JH, Ijzermans JN, de Bruin RW. The use of preoperative nutritional interventions to protect against hepatic ischemia-reperfusion injury. Liver transplantation : official publication of the American Association for the Study of Liver Diseases and the International Liver Transplantation Society. 2009;15(10):1183-1191.

41. Maltby JR. Preoperative fasting guidelines. Canadian journal of surgery Journal canadien de chirurgie. 2006;49(2):138-139; author reply 139.

42. López Muñoz AC, Busto Aguirreurreta N, Tomás Braulio J. Preoperative fasting guidelines: an update. Revista espanola de anestesiologia y reanimacion. 2015;62(3):145-156.

43. Rezende MU, Gurgel HM, Vilaca Junior PR, Kuroba RK, Lopes AS, Phillipi RZ, et al. Diacerhein versus glucosamine in a rat model of osteoarthritis. Clinics (Sao Paulo, Brazil). 2006;61(5):461-466.

44. Rai MF, Graeve T, Twardziok S, Schmidt MF. Evidence for regulated interleukin-4 expression in chondrocyte-scaffolds under in vitro inflammatory conditions. PloS one. 2011;6(10):e25749.

45. Innes JF, Gordon C, Vaughan-Thomas A, Rhodes NP, Clegg PD. Evaluation of cartilage, synovium and adipose tissue as cellular sources for osteochondral repair. Veterinary journal (London, England : 1997). 2013;197(3):619-624.

46. Livak KJ, Schmittgen TD. Analysis of relative gene expression data using real-time quantitative PCR and the $2^{\text {-DDCT }}$ Method. Methods (San Diego, Calif). 2001;25(4):402-408.

47. Hwang YI, Yoo YB, Baik SH. Comparative study of rat thyroid regeneration using PCNA and BrdU immunohistochemistry. Korean $\mathrm{J}$ Anat. 2000;33(2):247-254.

48. Hatori M, Klatte KJ, Teixeira CC, Shapiro IM. End labeling studies of fragmented DNA in the avian growth plate: evidence of apoptosis in terminally differentiated chondrocytes. Journal of bone and mineral research : the official journal of the American Society for Bone and Mineral Research. 1995;10(12):1960-1968.

49. Sailer ER, Schweizer S, Boden SE, Ammon HP, Safayhi H. Characterization of an acetyl-11-keto-beta-boswellic acid and arachidonate-binding regulatory site of 5-lipoxygenase using photoaffinity labeling. European journal of biochemistry. 1998;256(2):364-368.

50. Guo JS, Ou L, Zhou J, Wang XJ, Guo X. Impact 
on the model of rat osteoarthritis of jingu tablet. Zhongguo Zhong yao za zhi $=$ Zhongguo zhongyao zazhi $=$ China journal of Chinese materia medica. 2006;31(3):232-235.

51. Hardy MM, Seibert K, Manning PT, Currie MG, Woerner BM, Edwards D, et al. Cyclooxygenase 2-dependent prostaglandin $\mathrm{E}_{2}$ modulates cartilage proteoglycan degradation in human osteoarthritis explants. Arthritis and rheumatism. 2002;46(7):1789-1803.

52. Sakano Y, Terada N, Ueda H, Fujii Y, Hamada Y, Akamatsu N, et al. Histological study of articular cartilage in experimental rat knee arthritis induced by intracapsular injection of cationic polyethyleneimine. Medical electron microscopy : official journal of the Clinical Electron Microscopy Society of Japan. 2000;33(4):246-257.

53. Jiang D, Zou J, Huang L, Shi Q, Zhu X, Wang $G$, et al. Efficacy of intra-articular injection of celecoxib in a rabbit model of osteoarthritis. International journal of molecular sciences. 2010;11(10):4106-4113.

54. Kim JK, Park SW, Kang JW, Kim YJ, Lee SY, Shin J, et al. Effect of GCSB-5, a Herbal Formulation, on Monosodium Iodoacetate-Induced Osteoarthritis in Rats. Evidence-based complementary and alternative medicine : eCAM. 2012;2012:730907.

55. Syed Z, Khan A. Bone densitometry: applications and limitations. Journal of obstetrics and gynaecology Canada : JOGC = Journal d'obstetrique et gynecologie du Canada : JOGC. 2002;24(6):476-484.

56. Lee HS, Cho HR, Moon SB, Shin HD, Yang KJ, Park BR, et al. Effect of $\beta$-Glucan from Aureobasidium pullulans on Rat Rib Fracture Healing. Lab Anim Res. 2008;24(1):39-44.

57. Diez F. Guidelines for the diagnosis of osteoporosis by densitometric methods. Journal of manipulative and physiological therapeutics. 2002;25(6):403-415.

58. Karystinou A, Roelofs AJ, Neve A, Cantatore FP, Wackerhage H, De Bari C. Yes-associated protein (YAP) is a negative regulator of chondrogenesis in mesenchymal stem cells. Arthritis research \& therapy. 2015;17:147.

59. Tsouknidas A, Anagnostidis K, Panagiotidou S, Michailidis N. The effect of osteoarthritis on the regional anatomical variation of subchondral trabecular bone in the femoral head. Clinical biomechanics (Bristol, Avon). 2015;30(5):418-423.

60. Horcajada-Molteni MN, Crespy V, Coxam V, Davicco MJ, Rémésy C, Barlet JP. Rutin inhibits ovariectomy-induced osteopenia in rats. Journal of bone and mineral research : the official journal of the American Society for Bone and Mineral Research. 2000;15(11):2251-2258.

61. Bilston LE, Little DG, Smith NC, Williams P, Briody J. Zoledronic acid improves the mechanical properties of normal and healing bone. Clinical biomechanics (Bristol, Avon). 2002;17(9-10):716-718.

62. Bresnihan B. Pathogenesis of joint damage in rheumatoid arthritis. The Journal of rheumatology. 1999;26(3):717-719.

63. Nagase H, Woessner JF, Jr. Matrix metalloproteinases. The Journal of biological chemistry. 1999;274(31):21491-21494.

64. Halliwell B. Oral inflammation and reactive species: a missed opportunity? Oral diseases. 2000;6(3):136-137.

65. Armstrong S, Read R, Ghosh P. The effects of intraarticular hyaluronan on cartilage and subchondral bone changes in an ovine model of early osteoarthritis. The Journal of rheumatology. 1994;21(4):680-688.

66. Moore EE, Bendele AM, Thompson DL, Littau A, Waggie KS, Reardon B, et al. Fibroblast growth factor-18 stimulates chondrogenesis and cartilage repair in a rat model of injury-induced osteoarthritis. 
Anti-osteoarthritic effects of a combination of pomegranate concentrate powder, Eucommiae cortex and Achyranthis radix in rats

Osteoarthritis and cartilage. 2005;13(7):623-631.

67. Patel NA, Zoeller J, Stamper DL, Fujimoto JG, Brezinski ME. Monitoring osteoarthritis in the rat model using optical coherence tomography. IEEE transactions on medical imaging. 2005;24(2):155-159.

68. Cao L, Youn I, Guilak F, Setton LA. Compressive properties of mouse articular cartilage determined in a novel micro-indentation test method and biphasic finite element model. Journal of biomechanical engineering. 2006;128(5):766-771.

69. Hacker G. The morphology of apoptosis. Cell and tissue research. 2000;301(1):5-17.

70. Greenhalgh DG. The role of apoptosis in wound healing. The international journal of biochemistry \& cell biology. 1998;30(9):1019-1030.

71. Rahmati M, Nalesso G, Mobasheri A, Mozafari M. Aging and osteoarthritis: Central role of the extracellular matrix. Ageing research reviews. 2017;40:20-30

72. Ethier CR, Simmons CA. Introductory Biomechanics: From Cells to Organisms: Cambridge University Press; 2007.

73. Aigner T, Hemmel M, Neureiter D, Gebhard PM, Zeiler G, Kirchner T, et al. Apoptotic cell death is not a widespread phenomenon in normal aging and osteoarthritis human articular knee cartilage: a study of proliferation, programmed cell death (apoptosis), and viability of chondrocytes in normal and osteoarthritic human knee cartilage. Arthritis and rheumatism. 2001;44(6):1304-1312.

74. Heraud F, Heraud A, Harmand MF. Apoptosis in normal and osteoarthritic human articular cartilage. Annals of the rheumatic diseases. 2000;59(12):959-965.

75. Ganey T, Libera J, Moos V, Alasevic O, Fritsch $\mathrm{KG}$, Meisel HJ, et al. Disc chondrocyte transplantation in a canine model: a treatment for degenerated or damaged intervertebral disc. Spine. 2003;28(23):2609-2620.
76. Guzman RE, Evans MG, Bove S, Morenko B, Kilgore K. Mono-iodoacetate-induced histologic changes in subchondral bone and articular cartilage of rat femorotibial joints: an animal model of osteoarthritis. Toxicologic pathology. 2003;31(6):619-624.

77. Mundlos S, Olsen BR. Heritable diseases of the skeleton. Part I: Molecular insights into skeletal development-transcription factors and signaling pathways. FASEB journal : official publication of the Federation of American Societies for Experimental Biology. 1997;11(2):125-132.

78. Warnock JJ, Spina J, Bobe G, Duesterdieck-Zellmer KF, Ott J, Baltzer WI, Bay BK. Culture of canine synoviocytes on porcine intestinal submucosa scaffolds as a strategy for meniscal tissue engineering for treatment of meniscal injury in dogs. Veterinary journal (London, England : 1997). 2014;199(1):49-56.

\section{ORCID}

Sae-Kwang Ku: https://orcid.org/0000-0003-1269-3804

Young-Joon Lee: https://orcid.org/0000-0001-6439-9987 